\title{
Stabilization of tetragonal zirconia nanocrystallites using an original supercritical-based synthesis route
}

\section{Aimery Auxéméry, ${ }^{\dagger}$ Gilles Philippot, ${ }^{\dagger}$ Matthew R. Suchomel, ${ }^{\dagger}$ Denis Testemale,,${ }^{\S}$ and Cyril Aymonier ${ }^{\star \dagger}$}

\author{
${ }^{\dagger}$ CNRS, Univ. Bordeaux, Bordeaux INP, ICMCB, UMR 5026, F-33600 Pessac, France

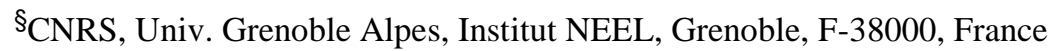

\begin{abstract}
To understand the importance of the particle size on the stabilization of metastable tetragonal $\mathrm{ZrO}_{2}$, ultra-fine $\mathrm{ZrO}_{2}$ nanocrystals were synthesized via: (i) the precipitation method in supercritical water using nitrate precursors, (ii) the sol-gel method in a supercritical ethanol-water mixture and (iii) the borderline non-hydrolytic sol-gel route in supercritical ethanol using propoxide precursors. The obtained nanocrystals displayed a variation of the monoclinic versus tetragonal molar fractions from $100 \mathrm{wt}$. $\%$ down to $\approx 10 \mathrm{wt}$. $\%$ of monoclinic phase. This variation was concomitant with an overall size decrease of the nanocrystals, ranging from 7 to $2 \mathrm{~nm}$ depending on the synthesis procedures. Phase contents were quantified by refinement analysis of X-ray scattering datasets, and crosschecked with Raman spectroscopy. Our results suggest that an upper limit of $\approx 90 \mathrm{wt}$. \%, of tetragonal $\mathrm{ZrO}_{2}$ phase is possible, even for ultra-fine nanoparticles $(2 \mathrm{~nm}$ ). These findings thus question the existence of any critical size limit below which stabilization of pure $\mathrm{t}-\mathrm{ZrO}_{2}$ is attainable at low temperatures.
\end{abstract}

\section{Introduction:}

Zirconium dioxide $\left(\mathrm{ZrO}_{2}\right)$ has been of major industrial and scientific interest over the past decades for its wide range of applications, in particular thanks to its catalytic properties ${ }^{1}$. Regardless the multiple synthesis routes employed such as: precipitation of metal salts ${ }^{2}$; atomic layer deposition ${ }^{3}$; ball-milling ${ }^{4}$; chemical vapor deposition ${ }^{5}$; radio frequency sputtering ${ }^{6}$; etc., undoped bulk $\mathrm{ZrO}_{2}$ is stabilized in the monoclinic structure (m$\mathrm{ZrO}_{2}$ ) at ambient temperature and atmospheric pressure. There, the small cationic size of $\mathrm{Zr}^{4+}$ covalently bonds to oxygen anions in a sevenfold coordination environment. However, improved catalytic properties are observed in tetragonal zirconia $\left(\mathrm{t}-\mathrm{ZrO}_{2}\right)$ where $\mathrm{Zr}^{4+}$ is coordinated with eight oxygen anions. To stabilize this allotrope under mild temperature and pressure conditions, it generally necessitates the use of iso- or aliovalent zirconium substitution of larger cationic radii ${ }^{7,8}$. For example, many works showed stabilized $\mathrm{t}-\mathrm{ZrO}_{2}$ through $\mathrm{Y}^{4+}, \mathrm{Ga}^{3+}, \mathrm{Gd}^{3+}$, $\mathrm{Fe}^{3+}$ substitution ${ }^{9-11}$. There, three main stabilization mechanisms are proposed: (i) the generation of structural defects such as lattice oxygen ion vacancies (L.O.I.V.) inducing structural variations in $\mathrm{ZrO}_{2}$ formation by changing zirconium coordination, from seven to eight-fold, (ii) the relieve of the internal strain associated with the dilatation of the network due to the substitution of $\mathrm{Zr}^{4+}$ with an oversized cation favoring the eightfold oxygen coordination and (iii) the combination of both mechanisms at the nanoscale ${ }^{12}$.

It is also possible to stabilize $\mathrm{t}-\mathrm{ZrO}_{2}$ without cationic substitution. To do so, three main effects are identified in the literature: (i) the presence of oxygen vacancies, (ii) the existence of structural similarities and (iii) the size effect.

(i) The influence of hydroxyl defects was highlighted with hydrothermal syntheses by adjusting the appropriate $\mathrm{pH}$ 13,14 . While low $\mathrm{pH}$ conditions $(\mathrm{pH}<3)$ generally enable stabilization of $\mathrm{m}-\mathrm{ZrO}_{2}$, high $\mathrm{pH}$ conditions $(\mathrm{pH}>9)$ favor the formation and stabilization of $\mathrm{t}-\mathrm{ZrO}_{2}$. The stabilization mechanism of $\mathrm{m}-\mathrm{ZrO}_{2}$ at low $\mathrm{pH}$ is believed to be due to the presence of
$\mathrm{Zr}(\mathrm{OH})_{2}{ }^{2+}$ clusters prior to nucleation, whereas at higher $\mathrm{pH}$ conditions, the increasing presence of $\mathrm{Zr}(\mathrm{OH})_{5}{ }^{-}$clusters allows the entrapment of hydroxyl groups inside the structure, thus triggering the nucleation and favoring the growth of $\mathrm{t}-\mathrm{ZrO}_{2}{ }^{14,15}$.

(ii) The existence of structural similarities was observed in the case of sol-gel syntheses using in situ $\mathrm{X}$ - ray scattering and Raman spectroscopy during crystallization of the gel ${ }^{16-19}$. This clearly revealed the existence of similarities (e.g., bond lengths) between the amorphous phase and the intermediate metastable $\mathrm{t}-\mathrm{ZrO}_{2}$ crystalline structure. Also, increasing annealing temperatures revealed that the stabilized metastable $\mathrm{t}-\mathrm{ZrO}_{2}$ structure was only an intermediate to the thermodynamically stable $\mathrm{m}-\mathrm{ZrO}_{2}$, as $\mathrm{t}-\mathrm{ZrO}_{2}$ inevitably transformed to $\mathrm{m}-\mathrm{ZrO}_{2}$ at $\approx$ $600^{\circ} \mathrm{C}$, far below the thermodynamic limit $\left(\approx 1205^{\circ} \mathrm{C}\right)$.

(iii) The concept of a size effect in the stabilization of t$\mathrm{ZrO}_{2}$ was first demonstrated in $1964^{20}$. Subsequently, numerous works have focused on identifying the threshold size for stabilizing $\mathrm{t}-\mathrm{ZrO}_{2}$ without dopants. Depending on the studies, sizes ranging from 2 to $30 \mathrm{~nm}{ }^{20-24}$ were found to be "critical" to stabilize $\mathrm{t}-\mathrm{ZrO}_{2}{ }^{25}$.

In 2005 many works were reviewed in a multimodel study focusing not only on the role of size effect, but also considering the influence of oxygen vacancies and structural similarities in the stabilization process for the whole 2 to $30 \mathrm{~nm}$ size range ${ }^{26}$. These same concepts have also recently been transposed to the stabilization of metastable $\mathrm{c}-\mathrm{ZrO}_{2}$ in ultrafine nanoparticles exhibiting sizes smaller than $2 \mathrm{~nm}^{27}$. However, the absence of a consensus regarding stabilization mechanisms in ultrafine $\mathrm{t}$ $\mathrm{ZrO}_{2}$ nanoparticles has led to propose that stabilization is system dependent.

Table 1 lists non-exhaustively the pros and cons of different syntheses routes generally used to synthesize $\mathrm{ZrO}_{2}$ nanoparticles. 
Table 1. Pros and cons of different syntheses routes for the formation of $\mathrm{ZrO}_{2}$ nanoparticles regarding the process duration, the existence or not of post synthesis steps and the quality of the produced powders in terms of average particle size (A.P.S.) and homogeneity.

\begin{tabular}{c|c|c|c|c|c} 
Processes & Duration & Post synthesis step(s) & A.P.S. (nm) & Homogeneity & Ref \\
\hline \hline Dry & & & & & \\
Solid state & Long & Milling, annealing & $7-17$ & Low & 28, \\
Deposition & Long & Drying, annealing & $4-40$ & Medium & $29,22,30$ \\
\hline Wet & & & & \\
Hydrothermal & Moderate & Drying & $8-30$ & High & 14,31 \\
Sol gel & Long & Drying, annealing & $7-500$ & High & $32,33,17,16,34,35$, \\
N.H.S.G. & Long & None & $2-4$ & Very high & $36,24,37$, \\
\hline Supercritical fluids & Short & None & $5-50$ & Very high & 38,39 \\
\hline \hline
\end{tabular}

It appears that both non-hydrolytic sol-gel (N.H.S.G.) reactions and the supercritical fluids technology offer the possibility to synthesize ultra-fine $\mathrm{ZrO}_{2}$ nanoparticles exhibiting very high size homogeneity and no post-synthesis step to finalize nanoparticle crystallization. However, though N.H.S.G. reactions allow the formation of almost pure $\mathrm{t}-\mathrm{ZrO}_{2}$ nanoparticles with fine control over size and size distribution ${ }^{19,24,40}$, the synthesis procedure is nevertheless long and generally requires the use of hazardous organic solvents such as oleylamine, trioctylphosphine oxide (TOPO) ${ }^{24,36}$ etc. In comparison the supercritical fluid technology which has been intensely developed over the past decades to circumvent the problem of environmental considerations and use of hazardous reactants appears to be an attractive alternative. In a supercritical approach, the solvent properties such as solvation ability, specific diffusivity, density and viscosity are modified, enabling nanoparticle crystallization in very short synthesis times with an excellent control over structure, morphology, size, and size distribution ${ }^{41-45}$. The technique has been used to synthesize ultrafine $\mathrm{ZrO}_{2}$ nanoparticles in both supercritical water and hydro-alcoholic mixtures. In these cases, the solvent choice is crucial; it is reported that the use of water lead to the synthesis of monoclinic nanoparticles 46-49, while using hydro-alcoholic mixtures, the produces particles exhibiting a mixture of monoclinic and tetragonal phases $38,46,50,51$

Based on this observation, the current work reported here studies the influence of water quantity in the media to synthesize t$\mathrm{ZrO}_{2}$ nanoparticles. Specifically, we examine for the first time the synthesis of $\mathrm{ZrO}_{2}$ nanocrystals in supercritical fluids using borderline non-hydrolytic sol-gel (B.N.H.S.G.) conditions. The term borderline is used to nuance from N.H.S.G. reactions when small amounts of water molecules are generated in situ from solvent decomposition to trigger hydrolysis/condensation reactions with metal precursors and the formation of oxo bridges prior to crystallization ${ }^{36,52,53}$. Playing on the experimental parameters we are able to fine tune the quantity of water generated in situ from the dehydration reaction of alcohols. In this context we chose zirconium propoxide precursors using ethanol $\left(\mathrm{p}_{\mathrm{C}}=\right.$ $6.27 \mathrm{MPa}, \mathrm{T}_{\mathrm{C}}=241.56^{\circ} \mathrm{C}$ ) as solvent, because the amount of water that can be generated upon pressure and temperature conditions has been quantified and reported in the literature ${ }^{54}$. Rapid crystallization of $\mathrm{ZrO}_{2}$ was realized in a short reaction time $\left(t_{R}=30 \mathrm{~s}\right)$ during simple single-step syntheses without re- quiring further annealing to obtain the final nanoparticles. Experiments were performed in supercritical water, in water ethanol 50 / 50 wt. \% mixture ${ }^{55,56}$ and in absolute ethanol with the aim to clarify the role of water in the formation of $\mathrm{t}-\mathrm{ZrO}_{2}$ nanoparticles. The size effect and more precisely the existence of a critical size below which only $\mathrm{t}-\mathrm{ZrO}_{2}$ is produced was also investigated by exploring the additional parameters of precursor concentration and the use of a surfactant. Indeed, the precursor concentration was investigated to optimize supersaturation conditions during the synthesis, with the goal of reducing the nanoparticle size. The influence of a carboxylic acid surfactant (hexanoic acid) was also studied to quench the nanoparticle growth. Following synthesis, the resulting powders were characterized by multiple probes (detailed below) in order to evaluate the effectiveness of varying conditions, and to compare the resulting crystalline polymorph types, fractions, and domain sizes at both local and long-range average length scales.

\section{Materials and method:}

\section{Materials:}

Zirconium(IV) oxynitrate hydrate (Sigma-Aldrich, $\geq 99 \%$ ), Zirconium(IV) propoxide solution, 70 wt. \% in 1-propanol (SigmaAldrich), hexanoic acid (Sigma-Aldrich, $\geq 99 \%$ ), absolute ethanol (Sharlau, $\geq 99.9 \%$ ) and de-ionized water were used as received.

\section{Apparatus and procedure:}

$\mathrm{ZrO}_{2}$ nanoparticles were synthesized using a continuous flow reactor designed to study how the water media content and precursor solution concentration influence the final structures. The influence of surfactants on the final crystallite structures and particle sizes was also evaluated. Zirconium(IV) propoxide solutions were prepared inside a glovebox under continuous argon flow to prevent zirconium precursors from reacting with air moisture. The solutions were then placed under magnetic stirring and argon flow during the syntheses to prevent contamination of the precursors. Nitrate precursors, which are not sensitive to air moisture were slowly dissolved in de-ionized water by moderate stirring under standard air atmosphere. 
As presented in Figure I, JASCO PU-2080 PLUS high-pressure pumps (HPP) were used to feed the reactor with the precursor solutions in the main injection line. Preheated water or ethanol could also be injected using the secondary line to play on the amount of water in the reactor. The hotzone reactor consisted of a coiled $5 \mathrm{~m}$ long $1 / 8$ ', SS-316 stainless steel tubing with an inner diameter of $1.58 \mathrm{~mm}$, for a total volume $V_{R}=8 \mathrm{~cm}^{3}$, inserted inside a heating clamp to control the desired reaction temperature $\left(400 \pm 2{ }^{\circ} \mathrm{C}\right)$. Thermal quenching of nanoparticle growth was realized by flowing the nanoparticle suspension through an ice-cooled 1/8' SS-316 stainless steel tubing downstream the reactor prior recover the powder and solvent at the outlet. The reactor was held at a constant pressure of $25 \mathrm{MPa}$ using a TESCOM ${ }^{\circledR}$ pressure-regulator valve (PRV).

\section{Synthesis of Zirconium dioxide nanoparticles:}

To evaluate the impact of water on the obtained structural mixtures, the following syntheses were realized: $\mathrm{ZrO}_{2}-01$ was synthesized from nitrate precursors in supercritical water. The second injection line was added to the reactor for the synthesis of $\mathrm{ZrO}_{2}-02$ and $\mathrm{ZrO}_{2}-03$ powders where either preheated water or ethanol were mixed to the zirconium propoxide precursor solution a few cm only from the reactor entrance to allow condensation of precursors prior to crystallization. The secondary line used to inject the desired volume of preheated water or ethanol was held at $25 \mathrm{MPa}$ and $225^{\circ} \mathrm{C}$, while the temperature at the mixing point was maintained at $150{ }^{\circ} \mathrm{C}$. Note that the main injection line was not preheated to avoid side reactions. $\mathrm{ZrO}_{2}-02$ was synthesized from zirconium propoxide precursor in a supercritical 50/50 water/ethanol weight ratio mixture using the two injection lines; and $\mathrm{ZrO}_{2}-03$ with the propoxide precursor in a supercritical mixture of ethanol and preheated ethanol using the two injection lines where water was generated in situ in the secondary line and in the main reactor after mixing. All three syntheses were performed with a precursor concentration $\left[\mathrm{Zr}^{4+}\right]$ $=10^{-2} \mathrm{~mol} / \mathrm{L} . \mathrm{ZrO}_{2}-04$ was synthesized with the same zirconium propoxide precursor concentration but only using the main injection line, thus reducing further the quantity of water generated in situ. Similarly, $\mathrm{ZrO}_{2}-05,06,07$ and 08 were all synthesized from zirconium propoxide precursors in supercritical ethanol using only one injection line, varying the precursor concentration $\left(\mathrm{ZrO}_{2}-04\right.$ to $\left.\mathrm{ZrO}_{2}-06\right)$ or adding hexanoic acid (HA) as surfactant $\left(\mathrm{ZrO}_{2}-07\right.$ and $\left.\mathrm{ZrO}_{2}-08\right)$.

To follow the influence of $\mathrm{Zr}^{4+}$ concentration, syntheses of $\mathrm{ZrO}_{2}-04\left(10^{-2} \mathrm{~mol} / \mathrm{L}\right), \mathrm{ZrO}_{2}-05\left(3.310^{-2} \mathrm{~mol} / \mathrm{L}\right)$, and $\mathrm{ZrO}_{2}-06$ $\left(6.610^{-2} \mathrm{~mol} / \mathrm{L}\right)$ were conducted in the same experimental conditions $\left(25 \mathrm{MPa}, 400{ }^{\circ} \mathrm{C}, 30 \mathrm{~s}\right)$. Finally, the influence of surfactant addition was observed by varying $\left[\mathrm{Zr}^{4+}\right]$ :[HA] molar ratios on $\mathrm{ZrO}_{2}-05$ (1:0), $\mathrm{ZrO}_{2}-07$ (1:6) and $\mathrm{ZrO}_{2}-08$ (1:12) with $\left[\mathrm{Zr}^{4+}\right]$ $=3.3310^{-2} \mathrm{~mol} / \mathrm{L}$. The residence time $\left(t_{R}\right)$ for each synthesis was fixed to $30 \mathrm{~s}$ determined with Equation 1,

$$
Q_{V}=\frac{V_{R} * \rho_{(H p, H T)}}{\boldsymbol{t}_{\boldsymbol{R}} * \boldsymbol{\rho}_{(H p, R T)}}
$$

where $V_{R}$ is the reactor total volume, $\rho_{(\mathrm{Hp}, \mathrm{HT})}$ and $\rho_{(\mathrm{Hp}, \mathrm{RT})}$ are the solvent densities at high pressure, high temperature and high pressure, room temperature, respectively. $Q_{V}$ is the total flow rate through the reactor. Values for the solvent densities for both conditions were obtained from the REFPROP software package $^{57}$. All synthesis conditions are displayed in Table 2 along with the results obtained from each ex situ characterization technique. Average crystallite sizes (A.C.S.) and lattice constants were determined from Rietveld refinements of powder X-ray diffraction (PXRD) data, Average particle sizes (A.P.S.) were determined from transmission electron microscopy (TEM), while PXRD and Raman spectroscopy probed polymorph phase proportions.

\section{Characterization techniques:}

Powder X-ray diffraction (PXRD) patterns were collected at room temperature on a PANalitycal X'pert PRO MPD diffractometer with the Bragg-Brentano $\theta-\theta$ geometry and over an angular range of $20 \leq 2 \theta \leq 70^{\circ}$ with a step size of $0.0167^{\circ}$. The diffractometer was equipped with a secondary graphite monochromator and the $\mathrm{Cu} \mathrm{K}_{\alpha 1}=1.5418 \AA$ radiation was generated at $45 \mathrm{kV}$ and $40 \mathrm{~mA}$. A multichannel X'Celerator detector was used to collect the XRD patterns. Powders were ground and sieved prior to measurements using a $40 \mu \mathrm{m}$ sieve. Data were analyzed by Rietveld structural model refinements using the FullProf software package ${ }^{58}$. The Thompson-Cox-Hasting formulation of the pseudo-Voigt function was used to fit the Bragg reflection profiles. In addition, the total reflection broadening was corrected for the instrumental contribution doing a reflection shape analysis of the diffraction pattern measured on a NIST LaB6 sample. The following parameters were refined; the background with the Chebyshev function, the scale, the lattice parameters, the Gaussian and Lorentzian contributions to the pick broadening and the $\mathrm{z}$ positon of the sample (see ESI for refinement patterns). Moreover, when the contribution from the

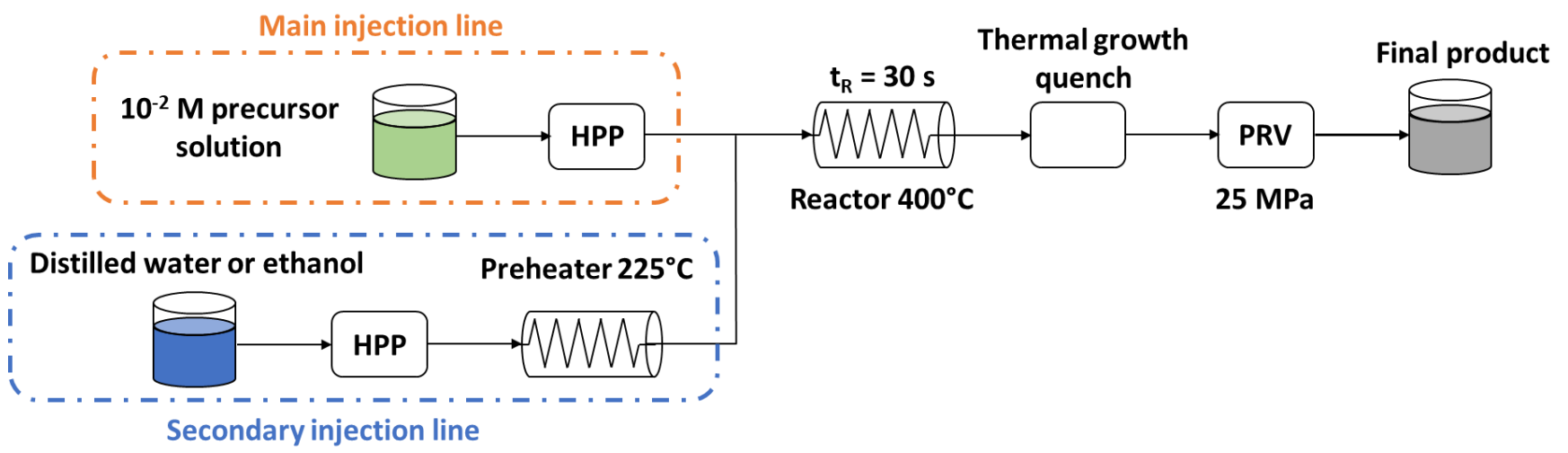

Figure I: Continuous flow reactor used in this study for the synthesis of $\mathrm{ZrO}_{2}$ nanoparticles. Nitrate or alkoxide zirconium precursors are dissolved in water or ethanol, respectively, in the precursor solution. 
monoclinic phase was too low, the lattice parameters were fixed to the last refined values.

Room temperature Raman spectra were collected using an XploRA HORIBA Scientific Raman spectrometer with $\lambda_{\mathrm{exc}}=$ $532 \mathrm{~nm}$ in a backscattering geometry and equipped with an Andor CCD detector. Data were collected with a resolution of 4 $\mathrm{cm}^{-1}$ over the $110-1700 \mathrm{~cm}^{-1}$ domain and were further integrated using the Labspec software.

Fourier transform infra-red (FTIR) spectroscopy was performed to determine the surface functionalization of the synthesized samples on a Brucker equinox 55 spectrophotometer. 32 scans was realized for each sample in the 400 and $4000 \mathrm{~cm}^{-1}$ spectral absorption domain using a global radiation source and the spectral resolution was $4 \mathrm{~cm}^{-1}$. The nanoparticles were ground and dispersed into a $\mathrm{KBr}$ matrix prior to measurements.

Particle size and morphology of the $\mathrm{ZrO}_{2}$ powders were observed using both a TEM-JEOL 2100 (200 keV) and a HRTEMFEG JEOL 2200FS (200 keV). Digital Micrograph software was used to process the acquired images. Samples were dispersed in ethanol and deposited on copper-carbon grids for analysis.
Extended X-ray absorption fine structure (EXAFS) measurements were performed on $\mathrm{ZrO}_{2}-05$ at the $\mathrm{Zr} \mathrm{K}$ edge (17.998 $\mathrm{keV}$ ) at the BM30B - FAME beamline at the European synchrotron radiation source (ESRF) in Grenoble. ${ }^{59}$ The beam size was $100 \times 300 \mu \mathrm{m}^{2}$ (FWHM) and the energy range was set between $17.8 \mathrm{keV}$ and $19 \mathrm{keV}$. Measurements were performed in transmission mode to collect both incident and transmitted photons. Data were fitted using Demeter 0.9.26 software ${ }^{60}$ after fitting the EXAFS of a zirconium metal foil to calibrate the $\mathrm{E}_{0}$ on the absorption edge (reference). The amplitude reduction factor $\left(S_{0}^{2}\right)$ was set to 0.77 after fitting data from zirconium metal foil. FEFF $^{\circledR}$ program was used to simulate multiple scattering calculations of X-ray Absorption Fine Structure of undoped tetragonal $\mathrm{ZrO}_{2}$ nanocrystals (ICSD file \#92091) and used as starting point for the structural refinement. The refined parameters where: the number of oxygen atoms $\left(\mathrm{N}_{\mathrm{O} \text { (I) }}\right.$ and $\left.\mathrm{N}_{\mathrm{O} \text { (II) }}\right)$ in the first and second shells; the number of zirconium atoms $\left(\mathrm{N}_{\mathrm{Zr}}\right)$ in the third shell; the energy shift $\left(\Delta \mathrm{E}_{0}\right)$; the adjustment of the half path length $\left(\mathrm{R}_{\mathrm{Zr}-\mathrm{O} \text { (I) }}, \mathrm{R}_{\mathrm{Zr}-\mathrm{O} \text { (II) }}\right.$ and $\left.\mathrm{R}_{\mathrm{Zr}-\mathrm{Zr}}\right)$; and the relative mean square displacement related to the half path length $\left(\sigma^{2}\right)$. The nanoparticles were ground and dispersed into a boron nitride matrix and pressed into pellets ( $5 \mathrm{~mm}$ in diameter and $2 \mathrm{~mm}$ thick) prior to measurements.

Table 2. Experimental conditions and characterization results for all samples in the present study.

\begin{tabular}{|c|c|c|c|c|c|c|c|c|}
\hline & $\mathrm{ZrO}_{2}-01$ & $\mathrm{ZrO}_{2-02}$ & $\mathrm{ZrO}_{2}-03$ & $\mathrm{ZrO}_{2}-04$ & $\mathrm{ZrO}_{2}-05$ & $\mathrm{ZrO}_{2-06}$ & $\mathrm{ZrO}_{2-07}$ & $\mathrm{ZrO}_{2-08}$ \\
\hline Injection lines & 1 & 2 & 2 & 1 & 1 & 1 & 1 & 1 \\
\hline Solvent & $\mathrm{H}_{2} \mathrm{O}$ & $\begin{array}{c}\mathrm{H}_{2} \mathrm{O} / \\
\text { Ethanol }\end{array}$ & $\begin{array}{c}\text { Ethanol / } \\
\text { Ethanol }\end{array}$ & Ethanol & Ethanol & Ethanol & Ethanol & Ethanol \\
\hline Water mol. \% & 100 & 71 & 1.9 & 0.8 & $<0.8$ & $<0.8$ & $<0.8$ & $<0.8$ \\
\hline$p(M P a)$ & 25 & 25 & 25 & 25 & 25 & 25 & 25 & 25 \\
\hline$T\left({ }^{\circ} \mathrm{C}\right)$ & 400 & 400 & 400 & 400 & 400 & 400 & 400 & 400 \\
\hline $\begin{array}{l}\text { Flow rate } \\
\left(\mathrm{mL} / \mathrm{min}^{-1}\right)\end{array}$ & 8 & $4 / 3.25$ & $3.25 / 3.25$ & 6.5 & 6.5 & 6.5 & 6.5 & 6.5 \\
\hline$\left[\mathrm{Zr}^{4+}\right](\mathrm{mol} / \mathrm{L})$ & $10^{-2}$ & $10^{-2}$ & $10^{-2}$ & $10^{-2}$ & $3.310^{-2}$ & $6.610^{-2}$ & $3.310^{-2}$ & $3.310^{-2}$ \\
\hline$\left[\mathrm{Zr}^{4+}\right]:[\mathrm{HA}]$ & - & - & - & - & - & - & $1: 6$ & $1: 12$ \\
\hline $\begin{array}{c}\text { m-ZrO } \mathrm{Zrt}_{2} \% \\
\text { Raman }\end{array}$ & 100 & $70 \pm 5$ & $40 \pm 4$ & $29 \pm 4$ & $11 \pm 3$ & $12 \pm 3$ & $15 \pm 3$ & $16 \pm 3$ \\
\hline $\begin{array}{c}m-\mathrm{ZrO}_{2} \text { wt. } \% \\
\text { Rietveld }\end{array}$ & 100 & $60 \pm 1$ & $36 \pm 1$ & $19 \pm 1$ & $17 \pm 1$ & $13 \pm 1$ & $14 \pm 1$ & $17 \pm 1$ \\
\hline $\begin{array}{c}\text { m-ZrO} \mathrm{O}_{2} \text { A.C.S. } \\
\text { (nm) Rietveld }\end{array}$ & $4.2 \pm 0.1$ & $5.2 \pm 0.1$ & $5.0 \pm 0.1$ & $4.0 \pm 0.1$ & $4.0 \pm 0.1$ & $3.5 \pm 0.1$ & $3.0 \pm 0.1$ & $2.6 \pm 0.1$ \\
\hline $\begin{array}{l}\text { t-ZrO } \mathrm{O}_{2} \text { A.C.S. } \\
\text { (nm) Rietveld }\end{array}$ & - & $4.7 \pm 0.1$ & $5.5 \pm 0.1$ & $3.9 \pm 0.1$ & $3.7 \pm 0.1$ & $2.8 \pm 0.1$ & $2.4 \pm 0.1$ & $2.4 \pm 0.1$ \\
\hline A.P.S. (nm) TEM & $6.6 \pm 1.2$ & $6.0 \pm 0.9$ & $5.0 \pm 1.0$ & $4.3 \pm 0.6$ & $3.7 \pm 0.5$ & $3.9 \pm 0.6$ & $3.8 \pm 0.4$ & $3.2 \pm 0.5$ \\
\hline $\begin{array}{c}m-\mathrm{ZrO}_{2} \\
\text { lattice } \\
\text { parameters }(\AA)\end{array}$ & $\begin{array}{l}a=5.158(1) \\
b=5.201(1) \\
c=5.313(1)\end{array}$ & $\begin{array}{l}a=5.154(1) \\
b=5.204(1) \\
c=5.322(1)\end{array}$ & $\begin{array}{l}a=5.165(1) \\
b=5.193(2) \\
c=5.344(2)\end{array}$ & $\begin{array}{l}a=5.165(1) \\
b=5.193(2) \\
c=5.344(2)\end{array}$ & $\begin{array}{l}a=5.165(1) \\
b=5.193(2) \\
c=5.344(2)\end{array}$ & $\begin{array}{l}a=5.165(1) \\
b=5.193(2) \\
c=5.344(2)\end{array}$ & $\begin{array}{l}a=5.165(1) \\
b=5.193(2) \\
c=5.344(2)\end{array}$ & $\begin{array}{l}a=5.165(1) \\
b=5.193(2) \\
c=5.344(2)\end{array}$ \\
\hline $\begin{array}{c}t-\mathrm{ZrO}_{2} \\
\text { lattice } \\
\text { parameters }(\AA)\end{array}$ & - & $\begin{array}{l}a=3.602(1) \\
\mathrm{c}=5.174(2)\end{array}$ & $\begin{array}{l}a=3.601(1) \\
c=5.182(1)\end{array}$ & $\begin{array}{l}a=3.605(1) \\
\mathrm{c}=5.156(2)\end{array}$ & $\begin{array}{l}a=3.603(1) \\
\mathrm{c}=5.134(3)\end{array}$ & $\begin{array}{l}a=3.621(1) \\
\mathrm{c}=5.083(2)\end{array}$ & $\begin{array}{l}a=3.643(1) \\
c=5.046(2)\end{array}$ & $\begin{array}{l}a=3.646(1) \\
c=5.034(2)\end{array}$ \\
\hline$R$-factor & 3.43 & $\begin{array}{c}m: 3.43 \\
t: 2.56 \\
\end{array}$ & $\begin{array}{c}m: 4.44 \\
t: 4.85 \\
\end{array}$ & $\begin{array}{c}m: 8.95 \\
t: 8.16 \\
\end{array}$ & $\begin{array}{c}m: 5.34 \\
t: 2.44 \\
\end{array}$ & $\begin{array}{c}m: 6.05 \\
t: 4.32 \\
\end{array}$ & $\begin{array}{c}m: 4.67 \\
t: 3.44 \\
\end{array}$ & $\begin{array}{c}m: 4.57 \\
t: 3.93 \\
\end{array}$ \\
\hline Chi $^{2}$ & 1.52 & 1.31 & 1.39 & 1.72 & 1.46 & 1.42 & 1.25 & 1.38 \\
\hline
\end{tabular}

Refined fits of the Raman spectra are displayed in the supplementary information in Figure S1 
Pair distribution function (PDF) analysis was performed after collecting high energy $(76.7 \mathrm{keV})$ total $\mathrm{X}$-ray scattering intensities of $\mathrm{ZrO}_{2}-02,05$ and 06 powders at room temperature inside $1.0 \mathrm{~mm}$ diameter glass capillaries loaded with $\mathrm{ZrO}_{2}$ powders at the XPDF (i15-1) beamline (Diamond synchrotron, UK) using the rapid-access program. Differential correlation function $\mathrm{D}(\mathrm{r})$ datasets were obtained from the 2D scattering data with the DAWN and GudrunX software packages and fitting of the realspace $\mathrm{D}(\mathrm{r})$ data were performed with the TOPAS v6 software package using a dQ_damping() macro term of $0.075^{61}$. Phase fractions and lattice parameters for $\mathrm{m}$ - and $\mathrm{t}-\mathrm{ZrO} 2$ allotropes and spherical crystallite domain diameter sizes were refined.

\section{Results and discussion:}

PXRD patterns of $\mathrm{ZrO}_{2}$ powders recovered after continuous flow synthesis are plotted in Figure II over the $20<2 \theta<70^{\circ}$ range and compared with the expected hkl reflection positions and relative intensities for $\mathrm{m}$ - and $\mathrm{t}-\mathrm{ZrO}_{2}$ polymorphs (from the ICSD database collection codes 82543 and 92091, respectively). The weight fraction (\%) and A.C.S (nm) of $\mathrm{m}-$ and $\mathrm{t}-$ $\mathrm{ZrO}_{2}$ obtained from Rietveld refinements of $\mathrm{ZrO}_{2}$ powder PXRD data are listed in Table 2. The PXRD reflections for sample $\mathrm{ZrO}_{2}-01$ show a clear visual agreement with expected m$\mathrm{ZrO}_{2}$ Bragg reflections - as evidenced by intense reflections at $2 \theta$ values of $\approx 24.2^{\circ}, 28.3^{\circ}$, and $31.5^{\circ},(011)_{\mathrm{m}},(11-1)_{\mathrm{m}}$, and $(111)_{\mathrm{m}}$ reflections, respectively. However samples $\mathrm{ZrO}_{2}-02$ to $\mathrm{ZrO}_{2}-05$ show a clear indication of drastically increasing $\mathrm{t}-\mathrm{ZrO}_{2}$ phase content evidenced by the single $(101)_{\mathrm{t}}$ reflection located at $2 \theta \approx 33.3^{\circ}$. Bragg reflections for the $\mathrm{m}-\mathrm{ZrO}_{2}$ phase are barely visible in the PXRD data from samples $\mathrm{ZrO}_{2}-05$ to $\mathrm{ZrO}_{2}-08$.

Based on Rietveld analysis of PXRD data for the samples with equivalent precursor concentrations, the refined weight percentage of $\mathrm{m}-\mathrm{ZrO}_{2}$ decreases with a reduction in water molar fraction, from $100 \%$ down to $60 \%, 36$ and $19 \%$ for the samples
$\mathrm{ZrO}_{2}-01,02,03$ and 04, respectively. The refined $\mathrm{m}-\mathrm{ZrO}_{2}$ weight fraction is then relatively constant (average $\approx 15 \mathrm{wt} . \%$ ) for samples $\mathrm{ZrO}_{2}-05,-06,-07$, and -08 despite varying precursor and surfactant (HA) concentrations. The A.C.S. obtained after Rietveld refinements show that $\mathrm{m}-\mathrm{ZrO}_{2}$ A.C.S. is a bit smaller for $\mathrm{ZrO}_{2}-01(4.2 \mathrm{~nm})$ in comparison with $\mathrm{ZrO}_{2}-02$ and $\mathrm{ZrO}_{2}-03$ where the A.C.S. is around $5 \mathrm{~nm}$. Such difference can be explained by the difference of chemistry (precursor nature) between the first synthesis and the others. The overall trend regarding the tetragonal phase shows an A.C.S. constant decrease from $\approx 5 \mathrm{~nm}\left(\mathrm{ZrO}_{2}-02\right.$ and $\left.\mathrm{ZrO}_{2}-03\right)$ down to $2.4 \mathrm{~nm}\left(\mathrm{ZrO}_{2}-07\right.$ and $\left.\mathrm{ZrO}_{2}-08\right)$. And is illustrate with the $(101)_{\mathrm{t}}$ reflection broadening, visible for samples $\mathrm{ZrO}_{2}-03$ to 08 , together with the $(101)_{t}$ reflection shift that generally accompanies decreases in particle size due to the bond distance distortion, related to the increase in L.O.I.V. ${ }^{46}$. Indeed, the $a$ and $b$ lattice parameters of the tetragonal phase are initially constant for $\mathrm{ZrO}_{2}-02$ to $\mathrm{ZrO}_{2}-$ 05 with a value around $3.603 \AA$ and then progressively increase up to $3.646 \AA$ for $\mathrm{ZrO}_{2}-08$. The lattice parameters $c$ is progressively decreasing from $\approx 5.180 \AA\left(\mathrm{ZrO}_{2}-02\right.$ and $\left.\mathrm{ZrO}_{2}-03\right)$ down to $5.034 \AA\left(\mathrm{ZrO}_{2}-07\right.$ and $\left.\mathrm{ZrO}_{2}-08\right)$. This illustrate a progressive transition towards a more cubic phase which is the one stable at even high temperature than the tetragonal one in the bulk. The lattice parameters of the monoclinic phase are slightly changing for $\mathrm{ZrO}_{2}-01$ to $\mathrm{ZrO}_{2}-03$ but where fixed for the other fits. Indeed, the quantity of the monoclinic phase decreasing, it was more and more difficult to have a converging refinement.

Fourier transform infra-red spectroscopy (FTIR) measurements were performed to evaluate the effectiveness of surface functionalization with $\mathrm{HA}$ over the synthesized $\mathrm{ZrO}_{2}$ nanoparticles $\left(\mathrm{ZrO}_{2}-07\right.$ and $\left.\mathrm{ZrO}_{2}-08\right)$. Figure III shows the FTIR spectra for $\mathrm{ZrO}_{2}-05,07$ and 08 containing 1:0, 1:6 and 1:12 [ $\left.\mathrm{Zr}^{4+}\right]:[\mathrm{HA}]$ molar ratios, respectively. In the $2800-3000 \mathrm{~cm}^{-1}$ region, $\mathrm{CH}_{2}$ and $\mathrm{CH}_{3}$ stretching vibrations are clearly visible for the functionalized samples $\left(\mathrm{ZrO}_{2}-07\right.$ and 08 , Figure III b and c) while

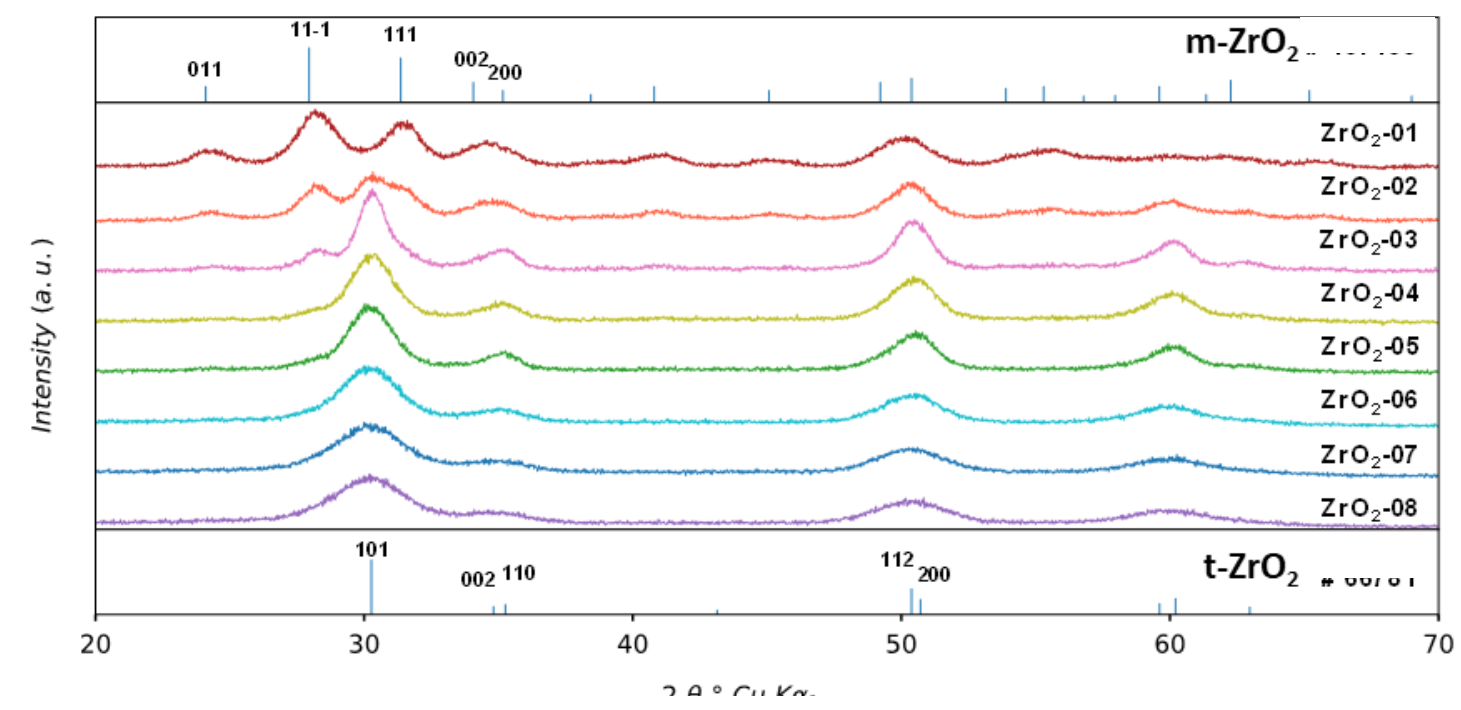

Figure II: X-ray diffraction patterns of $\mathrm{ZrO}_{2}$ powders in the 20 to $70^{\circ} 2 \Theta$ range, emphasizing the change in structure depending on the amount of water available for the synthesis $\left(\mathrm{ZrO}_{2}-01\right.$ to 04$)$, the precursor concentration $\left(\mathrm{ZrO}_{2}-05\right.$ and 06$)$, and the use of surfactants $\left(\mathrm{ZrO}_{2}-07\right.$ and 08$) . \mathrm{m}$ - and $\mathrm{t}-\mathrm{ZrO}_{2}$ structures are represented and indexed above and below the XRD patterns, respectively. 


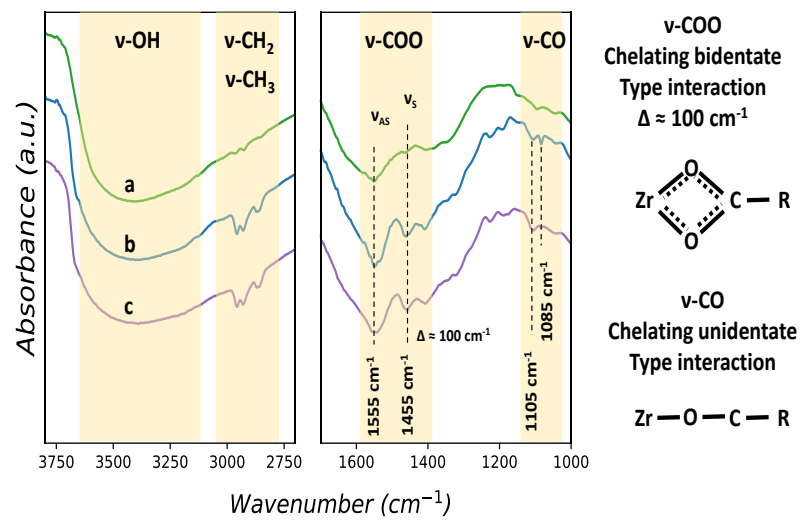

Figure III: FTIR spectra for a) $\mathrm{ZrO}_{2}-05$ powder without surfactant, b) $\mathrm{ZrO}_{2}-07$ with a 1:6 molar ratio of $\left[\mathrm{Zr}^{4+}\right]$ :[HA] and c) $\mathrm{ZrO}_{2}-08$ containing a $1: 12\left[\mathrm{Zr}^{4+}\right]$ :[HA] molar ratio, confirming the surfactant grafting.

they are hardly visible for the non-functionalized sample $\left(\mathrm{ZrO}_{2}-\right.$ 05 , Figure III a). In the $1450-1560 \mathrm{~cm}^{-1}$ region, the difference $\Delta$ between the antisymmetric $\left(v_{\mathrm{AS}-\mathrm{COO}}\right)$ and symmetric $\left(v_{\mathrm{S}-\mathrm{COO}}\right)$ vibrations of the carboxylate groups (-COO), 1555 and 1455 $\mathrm{cm}^{-1}$, respectively is the signature of a chelating bidentate type interaction between the carboxylate function and metal oxide surface ${ }^{62}$. The presence of -CO stretching vibrations is also evidenced at the surface of functionalized samples at 1105 and $1085 \mathrm{~cm}^{-1}$ which are also the signature of the HA grafting at the surface of $\mathrm{ZrO}_{2}$. Also, FTIR absorption spectra reveal no significant intensity changes in the vibrational frequencies related to the adsorbed species when the amount of hexanoic acid is increased from 1:6 to $1: 12$ inside the precursor solution. The main difference is visible on the vibration band at $1085 \mathrm{~cm}^{-1}$, typical of alkoxide bonding, that disappears for $\mathrm{ZrO}_{2}-08$. This may be related to the fact that surface coverage by carboxylate species increases further, through chelating bidentate type interactions ${ }^{63}$ as the amount of hexanoic acid is increased between samples $\mathrm{ZrO}_{2}-07$ and $\mathrm{ZrO}_{2}-08$.

Raman spectroscopy was used for further structural characterization of $\mathrm{ZrO}_{2}$ powders as it is a reliable technique for precise characterization of both local crystal structure and local disorder. Figure IV shows the Raman spectra of $\mathrm{ZrO}_{2}$ powders, with the same color code as for XRD patterns in Figure II. Frequencies for the observed Raman active modes used as a basis for assignment of the peaks were found in the following literature $23,64,65$

Raman shifts located at 148, 270, 309, 463 and $638 \mathrm{~cm}^{-1}$ are active modes of $\mathrm{t}-\mathrm{ZrO}_{2}$ (labelled as $\mathrm{T}$ ), while those located at $179,191,222,333,345,381,476,502,537,557$ and $613 \mathrm{~cm}^{-1}$ are active modes of $\mathrm{m}-\mathrm{ZrO}_{2}$ (labelled as $\mathrm{M}$ ). Integrated areas underneath the peaks at $148(\mathrm{~T}), 270(\mathrm{~T}), 179(\mathrm{M})$ and $191 \mathrm{~cm}$ ${ }^{1}(\mathrm{M})$ were used to quantify, for each $\mathrm{ZrO}_{2}$ powder, m- and $\mathrm{t}$ $\mathrm{ZrO}_{2}$ molar fractions using Equations 2 and $3{ }^{66}$ :

$$
\begin{gathered}
X_{t}=\frac{I_{t}\left(148 \mathrm{~cm}^{-1}\right)+I_{t}\left(270 \mathrm{~cm}^{-1}\right)}{I_{t}\left(148 \mathrm{~cm}^{-1}\right)+I_{t}\left(270 \mathrm{~cm}^{-1}\right)+I_{m}\left(179 \mathrm{~cm}^{-1}\right)+I_{m}\left(191 \mathrm{~cm}^{-1}\right)} \\
X_{m}=1-X_{t}
\end{gathered}
$$

where $I_{m}$ and $I_{t}$ refer to the integrated areas, at given wavenumbers, of $\mathrm{m}$ - and $\mathrm{t}-\mathrm{ZrO}_{2}$ active modes, respectively and $\mathrm{X}_{\mathrm{m}}$ and $\mathrm{X}_{\mathrm{z}}$ being $\mathrm{m}$ - and $\mathrm{t}-\mathrm{ZrO}_{2}$ molar fractions contained inside each powder. Note that this method is estimated to be quantitatively accurate around 5\%, moreover, the measurements being local, they were performed at three different locations of the samples and averaged. The obtained weight fractions are listed in Table 2.

As expected, Raman spectrum of $\mathrm{ZrO}_{2}$ synthesized in supercritical water using nitrate precursors $\left(\mathrm{ZrO}_{2}-01\right)$ exhibits purely the monoclinic structure ${ }^{49,67}$. To understand the importance of water on the reactional pathway during $\mathrm{ZrO}_{2}$ synthesis, $\mathrm{ZrO}_{2}-$ 02 and 03 were synthesized with decreasing amounts of water available for hydrolysis and condensation of the zirconium propoxide precursor (see Table 2) prior to entering the reactor with a $50 / 50 \mathrm{wt}$. $\%$ of a water/ethanol mixture and preheated ethanol, respectively resulting in decreasing $\mathrm{m}-\mathrm{ZrO}_{2}$ wt. $\%$ as listed in Table $2 . \mathrm{ZrO}_{2}-04$, synthesized with the same precursor concentration resulted in even lower $\mathrm{m}-\mathrm{ZrO}_{2} \mathrm{wt} . \%$ as water was produced inside the reactor, unlike for $\mathrm{ZrO}_{2}-02$ and 03 . Such $\mathrm{m}-$ and $\mathrm{t}-\mathrm{ZrO}_{2}$ structural mixtures were already observed in a supercritical isopropyl alcohol and water mixture, where water was added to assure complete precursor condensation ${ }^{38}$.

While all $\mathrm{ZrO}_{2}$ powders, except $\mathrm{ZrO}_{2}-01$, reveal the presence $\mathrm{m}$ - and $\mathrm{t}-\mathrm{ZrO}_{2}$ Raman active modes, they are nevertheless characterized by different weight on structure intensity contributions. For $\mathrm{ZrO}_{2}-02$ to $\mathrm{ZrO}_{2}-05$, t- $\mathrm{ZrO}_{2}$ active modes at 148 and $270 \mathrm{~cm}^{-1}$ increase in intensity relatively to $\mathrm{m}-\mathrm{ZrO}_{2}$ modes at 179 and $191 \mathrm{~cm}^{-1}$. Also, in the $300-400 \mathrm{~cm}^{-1}$ domain, all three $\mathrm{m}$ $\mathrm{ZrO}_{2}$ active mode intensities dramatically decrease while the tetragonal mode at $309 \mathrm{~cm}^{-1}$ increases and broadens. It is important to note the presence of a slight signal at $309 \mathrm{~cm}^{-1}$ in $\mathrm{ZrO}_{2}-01$ (labelled as $\mathrm{t}$ in Figure I), probably corresponding to traces of $\mathrm{t}-\mathrm{ZrO}_{2}$ in the synthesized powder. The same trend is observed in the 476-620 $\mathrm{cm}^{-1}$ domain, and specially for $\mathrm{ZrO}_{2}$ 05 where both modes at 537 and $557 \mathrm{~cm}^{-1}$ have disappeared. On the other hand, for these samples, all five $\mathrm{t}-\mathrm{ZrO}_{2}$ Raman mode intensities increase in the order from $\mathrm{ZrO}_{2}-02$ to $\mathrm{ZrO}_{2}-05$, with no exception. However, concerning $\mathrm{ZrO}_{2}-06,07$ and 08 , the major differences are visible on the $\mathrm{t}-\mathrm{ZrO}_{2}$ modes at 148 and 270 $\mathrm{cm}^{-1}$ and $\mathrm{m}-\mathrm{ZrO}_{2}$ modes at 179 and $191 \mathrm{~cm}^{-1}$, where a slight increase in $\mathrm{m}-\mathrm{ZrO}_{2}$ relatively to $\mathrm{t}-\mathrm{ZrO}_{2}$ modes are observed. These intensity variations reveal slight structure proportions variations in the powders. Proportions obtained from Equation 2 give $\approx 70,40,29$ and 11 wt. $\% \mathrm{~m}-\mathrm{ZrO}_{2}$ for $\mathrm{ZrO}_{2}-02,03,04$ and 05 , respectively and $\approx 12,15$ and 16 wt. $\% \mathrm{~m}-\mathrm{ZrO}_{2}$ for $\mathrm{ZrO}_{2}-06,07$ and 08, respectively.

Despite slight discrepancies in quantification of $\mathrm{m}-\mathrm{ZrO}_{2}$ phase fraction between the PXRD and Raman techniques, the exact same trend is observed for both probes, revealing unequivocally the presence of a mixture of both structures. For the PXRD analysis of $\mathrm{t}-\mathrm{ZrO}_{2}$ rich samples, quantification of $\mathrm{m}-\mathrm{ZrO}_{2}$ phase content might be considered limited by instrumental signal-tonoise statistics and intrinsic sample peak broadening. However Raman spectroscopy certainly has the ability to clearly discern each structure present in our ultra-fine synthesized nanoparticles. The decreasing proportion of $\mathrm{m}-\mathrm{ZrO}_{2}$ is, first of all, believed to be due to the decreasing amounts of water available dictated by the experimental conditions used. Indeed, water 


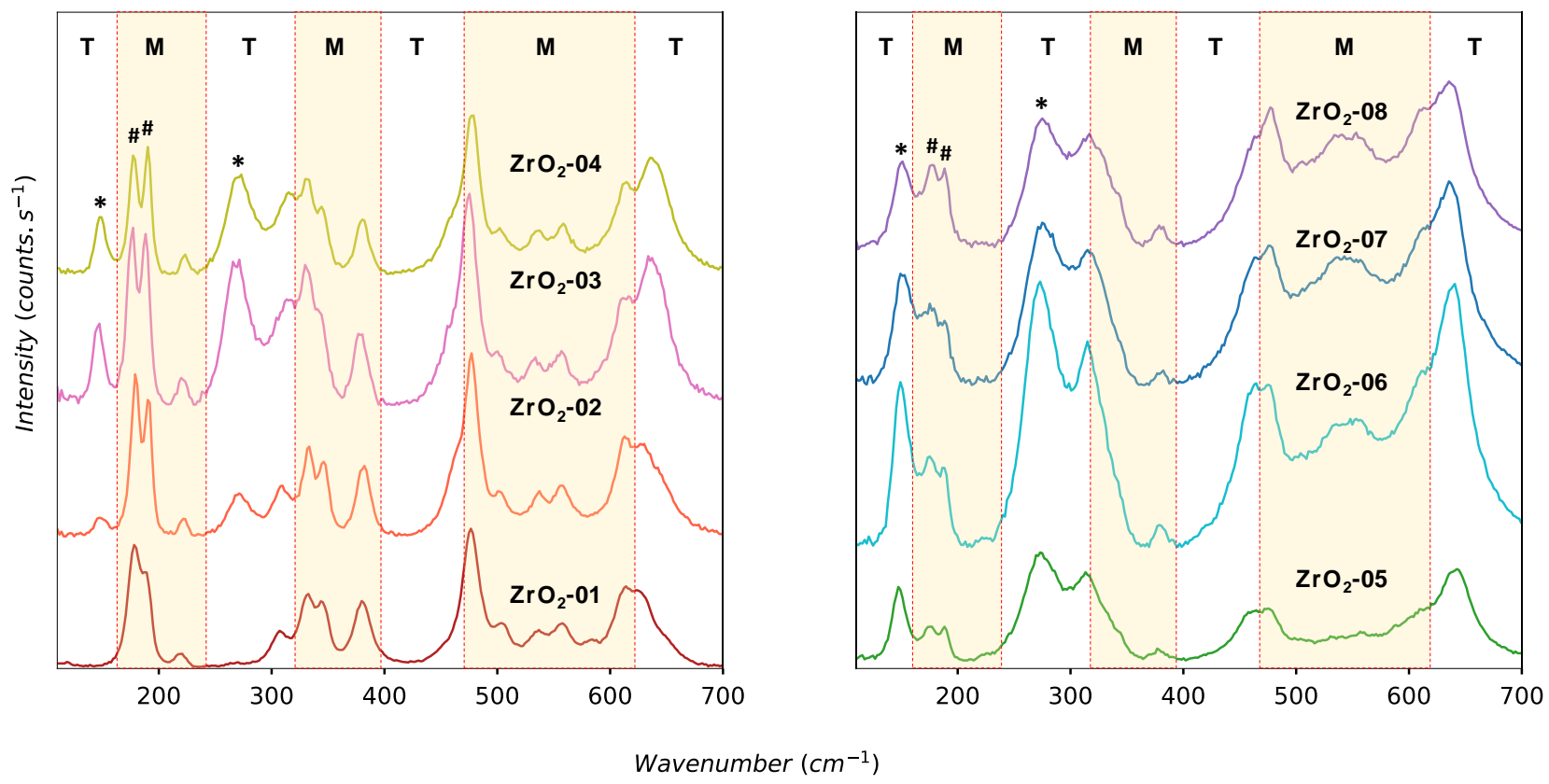

Figure IV: Raman spectra of $\mathrm{ZrO}_{2}$ powders collected at room temperature in the $110-700 \mathrm{~cm}^{-1}$ domain. Raman spectra were separated for clarity purposes: on the left hand side, those displaying a $\left[\mathrm{Zr}^{4+}\right]=10^{-2} \mathrm{~mol} / \mathrm{L},\left(\mathrm{ZrO}_{2}-01\right.$ to $\left.\mathrm{ZrO}_{2}-04\right)$ and decreasing $\mathrm{m}-\mathrm{ZrO}_{2}$ content; while those on the right hand side with stabilized $\mathrm{m}-\mathrm{ZrO}_{2}$ content $\left(\mathrm{ZrO}_{2}-05\right.$ to $\left.\mathrm{ZrO}_{2}-08\right)$. The monoclinic (M) and tetragonal $(\mathrm{T})$ domains are separated by red dashed-lines and $\mathrm{t}-$ and $\mathrm{m}-\mathrm{ZrO}_{2}$ Raman modes used for the quantification of each phase are represented by $*$ and \# symbols, respectively.

mol. \% inside the reactor are 100 mol. $\%, 71$ mol. $\%, 1.9$ mol. $\%$ and 0.8 mol. $\%$ for $\mathrm{ZrO}_{2}-01,02,03$ and-04, respectively. Contribution from ethanol dehydration was calculated from works realized on by-products formed in organic solvents and quantified under solvothermal conditions ${ }^{54}$. But also, the varying $\mathrm{m}-\mathrm{ZrO}_{2}$ wt. \% can be explained by the initial prepolymerization of nuclei with local structures close to $\mathrm{m}-\mathrm{ZrO}_{2}$, in mild hydrothermal conditions at the mixing point at $150^{\circ} \mathrm{C}$, thus facilitating $\mathrm{ZrO}_{7}$ polyhedra packing ${ }^{68}$ when two injection lines are used.

The decrease in $\mathrm{m}-\mathrm{ZrO}_{2}$ fraction observed between $\mathrm{ZrO}_{2}-04,05$ and 06 , is believed to be influenced by the increase in precursor concentration with $\left[\mathrm{Zr}^{4+}\right]=10^{-2}, 3.310^{-2}$ and $6.610^{-2} \mathrm{~mol} / \mathrm{L}$, respectively and optimization of supersaturation conditions to form stabilized ultrafine $\mathrm{ZrO}_{2}$ nanoparticles. However, the difference in $\mathrm{m}-\mathrm{ZrO}_{2}$ content between $\mathrm{ZrO}_{2}-05$ (11 wt. \% m- $\mathrm{ZrO}_{2}$ ) and $06\left(12 \mathrm{wt} \% \mathrm{~m}-\mathrm{ZrO}_{2}\right)$ is insignificant, showing that the optimal supersaturation conditions were met with $\left[\mathrm{Zr}^{4+}\right]=3.310^{-}$ ${ }^{2} \mathrm{~mol} / \mathrm{L}$.

For the third set of experiments based on the addition of surfactants to the precursor solution, visual inspection of PXRD patterns do not seem to reveal peak signatures of $\mathrm{m}-\mathrm{ZrO}_{2}$ due to the large decrease in intensity of the (11-1) $\mathrm{m}$ reflection and the large broadening of the $(011)_{\mathrm{t}}$ plane related to the decrease in the $\mathrm{t}-\mathrm{ZrO}_{2}$ A.C.S. $(\approx 2-3 \mathrm{~nm})$. But Rietveld refinements realized on these samples show that non-negligible amounts of $\mathrm{m}$ $\mathrm{ZrO}_{2}$ are nevertheless present in the final powders. This result is confirmed by the good quantitate agreement in $\mathrm{m}$ - and $\mathrm{t}-\mathrm{ZrO}_{2}$ proportions obtained from both Rietveld PXRD refinements and Raman spectroscopy analysis which also seems to reveal that increasing hexanoic acid contents in the precursor solution leads to a slight increase in $\mathrm{m}-\mathrm{ZrO}_{2}$ content in the final powders. The addition of hexanoic acid slightly reduces both the $\mathrm{t}-\mathrm{ZrO}_{2}$ A.C.S. from $\approx 3 \mathrm{~nm}$ down to $\approx 2 \mathrm{~nm}$ as well as the $\mathrm{m}-\mathrm{ZrO}_{2}$ A.C.S. from $\approx 3.5 \mathrm{~nm}$ down to $\approx 2.5 \mathrm{~nm}$ for a $\left[\mathrm{Zr}^{4+}\right]$ : [HA] molar ratio equal to $1: 6$. Further increase in $\mathrm{HA}$ does not seem to modify anymore the $\mathrm{t}-\mathrm{ZrO}_{2}$ A.C.S. however, as $\mathrm{t}-\mathrm{ZrO}_{2}$ A.C.S. for $\mathrm{ZrO}_{2}-08$ is also $\approx 2 \mathrm{~nm}$.

Transmission electron microscope (TEM) and high-resolution transmission electron microscope (HRTEM) images of $\mathrm{ZrO}_{2}$ powders are shown in Figure V. Particle sizes were averaged over at least 70 particles for all samples to improve statistics on the mean particle size and standard deviation. $\mathrm{ZrO}_{2}$ nanoparticles are quasi-spherical in shape, and their particle sizes obtained from microscopy observations are listed in Table 2 alongside A.C.S. values obtained by Rietveld refinements. Besides the case of $\mathrm{ZrO}_{2}-01$ where a significant difference is observed with an A.C.S. of $4.2 \mathrm{~nm}$ and an A.P.S of $6.6 \mathrm{~nm}$ indicating that the particles are not to fully crystallized (linked to the difference in precursors), a good agreement is observed for the other samples confirming the size observations made by PXRD analysis. The selected area electron diffraction (SAED) images realized over a large number of $\mathrm{ZrO} 2$ nanoparticles show a high degree of crystallinity with an increasing quantity of the $\mathrm{t}-\mathrm{ZrO}_{2}$ phase from: $\mathrm{ZrO}_{2}-02$ (Figure $\mathrm{V} \mathrm{j}$ ) to $\mathrm{ZrO}_{2}-07$ (Figure $\mathrm{V} \mathrm{m}$ ). Also, A.P.S. observed by TEM, HRTEM and Rietveld refinements are very similar, and it can be seen (Table 2) that $\mathrm{t}-\mathrm{ZrO}_{2}$ nanoparticles are smaller than their $\mathrm{m}-\mathrm{ZrO}_{2}$ counterparts, which is actually the case for every sample composed of a mixture of $\mathrm{m}$ - and $\mathrm{t}-\mathrm{ZrO}_{2}$.

These first results show that, while the precursor concentration is increased, $\mathrm{m}-\mathrm{ZrO}_{2}$ A.C.S. decreases from $\approx 4 \mathrm{~nm}$ down to 3.5 

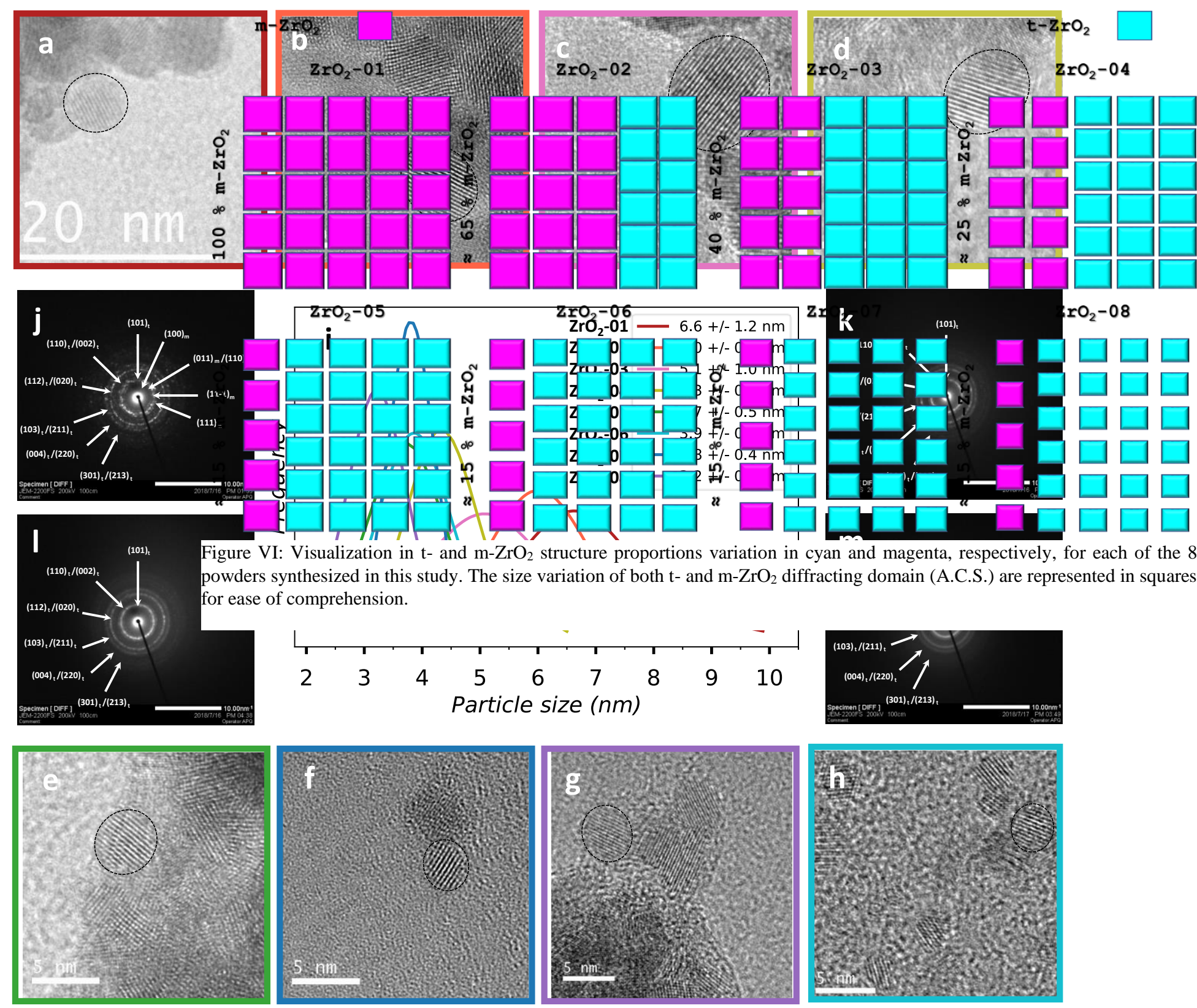

Figure V: a, TEM image of $\mathrm{ZrO}_{2}-01 . \mathrm{b}, \mathrm{c}, \mathrm{d}$, e, f, g and h are HRTEM images of $\mathrm{ZrO}_{2}-02,03,04,05,06,07$ and 08, respectively. i plot the particle size distribution for each sample, determined using a normal distribution function over the particle counts. $\mathrm{j}, \mathrm{k}, \mathrm{l}$ and $\mathrm{m}$ are diffraction images of $\mathrm{ZrO}_{2}-02,04,05$ and 07 , respectively. $\mathrm{t}-$ and $\mathrm{m}-\mathrm{ZrO}_{2}$ diffracting planes are labelled on the left- and right-hand side of the diffracting images, respectively.

$\mathrm{nm}$ and $\mathrm{t}-\mathrm{ZrO}_{2}$ A.C.S. decreases from $\approx 4$ down to $\approx 2.8 \mathrm{~nm}$. However, changes in concentrations do not significantly change the $\mathrm{m}$ - and $\mathrm{t}-\mathrm{ZrO}_{2}$ proportions inside the powders. Changing the concentration, while decreasing $\mathrm{t}-\mathrm{ZrO}_{2}$ size does not significantly seem to favor its formation in anyway in our experimental conditions, as can be seen on both Rietveld and Raman results (Table 2). Figure VI illustrates the correlation between structural proportion variations and nanoparticle A.C.S. between each synthesized powder in this study. In the first row of Figure VI ( $\mathrm{ZrO}_{2}-01$ to 04$)$ and more clearly on the histograms, we see a link between the size reduction and increase in $\mathrm{t}-\mathrm{ZrO}_{2}$ content inside the powder mixtures. However, in the second row $\left(\mathrm{ZrO}_{2}-05\right.$ to 08$)$ the trend is not revealed. As in the first row, all
A.C.S. are greater than but approaching the smallest critical size limit $(\approx 3 \mathrm{~nm})$ reported in literature, so the increase in $\mathrm{t}-\mathrm{ZrO}_{2}$ content can be explained by the critical size theory. On the other hand, in the second row, despite the fact that all A.C.S. values (for both $\mathrm{t}$ - and $\mathrm{m}-\mathrm{ZrO}_{2}$ ) are at or even below this lowest critical limit of $3 \mathrm{~nm}\left(\mathrm{t}-\mathrm{ZrO}_{2}\right)$, the phase fraction of $\mathrm{m}-\mathrm{ZrO}_{2}$ stagnates at $\approx 10-15$ wt. $\%$. Therefore, as the $\mathrm{t}^{-\mathrm{ZrO}_{2}}$ A.C.S. tend to decrease from $\mathrm{ZrO}_{2}-05$ to $\mathrm{ZrO}_{2}-08$, Figure VI clearly emphasizes the fact that $\mathrm{t}-\mathrm{ZrO}_{2}$ formation is favored as the nanocrystals size decreases down to an equilibrium limit of $\approx 85-90 \mathrm{wt}$. $\%$ of $\mathrm{t}-$ $\mathrm{ZrO}_{2}$. However, reducing the size even down to $\approx 2 \mathrm{~nm}$ does not further increase the relative wt. $\%$ of $\mathrm{t}-\mathrm{ZrO}_{2}$. These results show the limit of the size effect theory on the synthesis of pure $\mathrm{t}-\mathrm{ZrO}_{2}$ 
nanoparticles especially because we can stabilize $\mathrm{m}-\mathrm{ZrO}_{2}$ with A.C.S. smaller than $3 \mathrm{~nm}$ in the case of $\mathrm{ZrO}_{2}-08$. Figure VI also emphasizes that in our synthesis conditions, and probably in a general manner, $\mathrm{t}$ - and $\mathrm{m}-\mathrm{ZrO}_{2}$ nuclei are formed concomitantly, however, in situ studies focused specifically on $\mathrm{ZrO}_{2}$ nucleation would be necessary to validate the hypothesis.

PDF analysis of selected samples provides additional details on crystallite domain size and phase fractions. Differential correlation functions $\mathrm{D}(\mathrm{r})$ obtained from PDF measurements performed on powders $\mathrm{ZrO}_{2}-02,05$ and 06 are displayed in Figure VII in the 1.5-50 A range. Table 3 lists a summary of parameters refined against the $\mathrm{D}(\mathrm{r})$ functions, including $\mathrm{m}-\mathrm{ZrO}_{2}$ wt. \%, tand $\mathrm{m}-\mathrm{ZrO}_{2}$ cell volumes, and average crystallite domain size, for the samples $\mathrm{ZrO}_{2}-\mathrm{O} 2,05$ and 06 .

Table 3: Structural characteristics obtained from $D(r)$ refinements

\begin{tabular}{|c|c|c|c|}
\hline & $\mathrm{ZrO}_{2}-02$ & $\mathrm{ZrO}_{2}-05$ & $\mathrm{ZrO}_{2}-06$ \\
\hline$m-\mathrm{ZrO}_{2} w t . \%$ & $68.8(2)$ & $26.9(3)$ & $33.6(4)$ \\
\hline $\mathrm{t}-\mathrm{ZrO}_{2} \mathrm{Cell} \mathrm{Vol} / \mathrm{Z}\left(\AA^{3}\right)$ & $33.6(1)$ & $33.5(1)$ & $33.4(1)$ \\
\hline$m-\mathrm{ZrO}_{2} \mathrm{Cell} \mathrm{Vol} / \mathrm{Z}\left(\AA^{3}\right)$ & $35.3(1)$ & $35.4(1)$ & $35.4(1)$ \\
\hline Domain size $(\mathrm{nm})$ & $6.3 \pm 0.1$ & $5.5 \pm 0.1$ & $4.2 \pm 0.1$ \\
\hline$R_{W P}(\%)$ & 12.4 & 11.6 & 10.9 \\
\hline
\end{tabular}

The $\mathrm{D}(\mathrm{r})$ data, refined model and difference curves displayed in Figure VII show that the observed $\mathrm{ZrO}_{2}$ nanoparticles synthesized are highly ordered at a local scale and can be well described by a mixture of $\mathrm{m}-\mathrm{ZrO}_{2}$ and $\mathrm{t}-\mathrm{ZrO}_{2}$ structural models. Information obtained from $\mathrm{D}(\mathrm{r})$ refinements show that crystallite domain sizes are $\approx 6.3,5.5$ and $4.2 \mathrm{~nm}$ for $\mathrm{ZrO}_{2}-02,05$ and 06 , respectively, which is very close to values obtained from Rietveld PXRD refinements (5, 3.9 and $3.1 \mathrm{~nm}$, respectively). Also, from PDF analysis, $\mathrm{m}-\mathrm{ZrO}_{2}$ wt. $\%$ obtained from the refinements are $\approx 68,27$ and 34 for $\mathrm{ZrO}_{2}-02,05$ and 06, respectively. For $\mathrm{ZrO}_{2}-02$, this is in good agreement with Rietveld refinement (60 wt. \%) and Raman quantification (70 wt. \%). For $\mathrm{ZrO}_{2}-05$ the results start to diverge, with Rietveld refinement we obtained 17 wt. \% and with Raman quantification 11 wt. \%. This is even more pronounced for $\mathrm{ZrO}_{2}-04$ where Rietveld refinement gave 19 wt. \% and Raman quantification 29 wt. \%. Nevertheless, we have to keep in mind that, the Bragg reflection intensity of the monoclinic phase is much lower than the higher symmetry tetragonal phase, and thus, especially for low $\mathrm{m}-\mathrm{ZrO}_{2}$ phase fractions with small domain sizes, it is difficult to obtain a precise quantification by lab-based PXRD measurements in comparison with the superior signal-to noise and real space resolution of the synchrotron based PDF data. Similarly, the values obtained from the Raman quantification based on a lab scale apparatus can only give trends. On top of this there is still this crystal phase distortion at the surface of the particle resulting from the strain generated at this scale, and differences in probe sample depth sensitivity which should be considered. In conclusion, considering differences in the sensitivity and length scales probed (e.g. local vs long range ordering), we can conclude that the results are consistent, especially regarding the high degree of crystallinity of the particles since sizes from PXRD and PDF are similar. For the phase ratios, we can clearly see that reducing the amount of water during the synthesis (sample $\mathrm{ZrO}_{2}-02$ vs. samples $\mathrm{ZrO}_{2}-05$ and $\mathrm{ZrO}_{2}-06$ ) will clearly reduce the amount of monoclinic phase. The highest percentage of $\mathrm{t}-\mathrm{ZrO}_{2}$ in the series of samples was observed for $\mathrm{ZrO}_{2}-05$, based on both Rietveld refinements (17 wt. \%) and Raman spectroscopy (11 wt. \%). This was also confirmed with diffraction images collected on $\mathrm{ZrO}_{2}-05$ showing the lowest dispersion around $\mathrm{t}-\mathrm{ZrO}_{2}$ Bragg reflections as shown in Figure VII (1), thus implying lower amounts of $\mathrm{m}-\mathrm{ZrO}_{2}$ in the powder. EXAFS measurements were performed on $\mathrm{ZrO}_{2}-05$ with the objective, by probing the first $\mathrm{Zr}-\mathrm{O}$ and $\mathrm{Zr}-\mathrm{Zr}$ coordination shells around zirconium, to confirm the stabilization of a majority tetragonal-like phase. The fits were done for radial distances from $\mathrm{R}=1.5 \AA$ to $\mathrm{R}=4.5 \AA$ and for $\mathrm{k}$ values from 3.8 to 14.6 (Figure VIII). Considering the $\mathrm{Zr}-\mathrm{O}$ diffuse shell, the starting model present an arrangement of 8 backscattering $\mathrm{O}$ atoms around a central $\mathrm{Zr}$ absorbing atom. 4 $\mathrm{O}$ atoms $\left(\mathrm{N}_{\mathrm{O}(\mathrm{I})}\right)$ were distant of $2.00 \AA\left(\mathrm{R}_{\mathrm{Zr}-\mathrm{O}(\mathrm{I})}\right)$ and the other 4 $\left(\mathrm{N}_{\mathrm{O} \text { (II) }}\right)$ distant of $2.40 \AA\left(\mathrm{R}_{\mathrm{Zr}-\mathrm{O}(\mathrm{OII})}\right)$. The $\mathrm{Zr}$ - $\mathrm{Zr}$ diffuse shell was fitted using a single shell model of $12 \mathrm{Zr}$ atoms $\left(\mathrm{N}_{\mathrm{Zr}}\right)$ around a central $\mathrm{Zr}$ atom, with all $12 \mathrm{Zr}$ atoms distant of $3.56 \AA\left(\mathrm{R}_{\mathrm{Zr}-\mathrm{Zr}}\right)$. Values obtained after the refinement are detailed in Table 4.

Table 4. List of the EXAFS fitting results for $\mathrm{ZrO}_{2}-05$. For the interatomic distance refinements, the first subscript refers to the absorbing element $(\mathrm{Zr})$ while the second subscript refers to the backscattering element which can be either $\mathrm{Zr}, \mathbf{O}_{(\mathrm{I})}$ or $\mathbf{O}_{(\mathrm{II})}$ atoms.

\begin{tabular}{|c|c|}
\hline Independent points & 30 \\
\hline Number of variables & 22 \\
\hline$\Delta_{\mathrm{E} 0}(\mathrm{eV})$ & $0.0026 \pm 1.1625$ \\
\hline $\mathrm{No}_{\mathrm{O}(\mathrm{I})}$ & $5.9 \pm 1.1$ \\
\hline $\mathrm{N}_{\mathrm{O}(\mathrm{II})}$ & $2.7 \pm 0.6$ \\
\hline $\mathrm{N}_{\mathrm{Zr}}$ & $9.6 \pm 1.4$ \\
\hline $\mathrm{R}_{\mathrm{Zr}-\mathrm{O}(\mathrm{I})}(\AA)$ & $2.11 \pm 0.07$ \\
\hline $\mathrm{R}_{\mathrm{Zr}-\mathrm{O}(\mathrm{II})}(\AA)$ & $2.30 \pm 0.07$ \\
\hline $\mathrm{R}_{\mathrm{Zr}-\mathrm{Zr}}(\AA)$ & $3.64 \pm 0.09$ \\
\hline$\sigma^{2} \mathrm{O}\left(\AA^{2}\right)$ & $0.0050 \pm 0.0014$ \\
\hline$\sigma^{2} \mathrm{Zr}\left(\AA^{2}\right)$ & $0.0086 \pm 0.0009$ \\
\hline
\end{tabular}




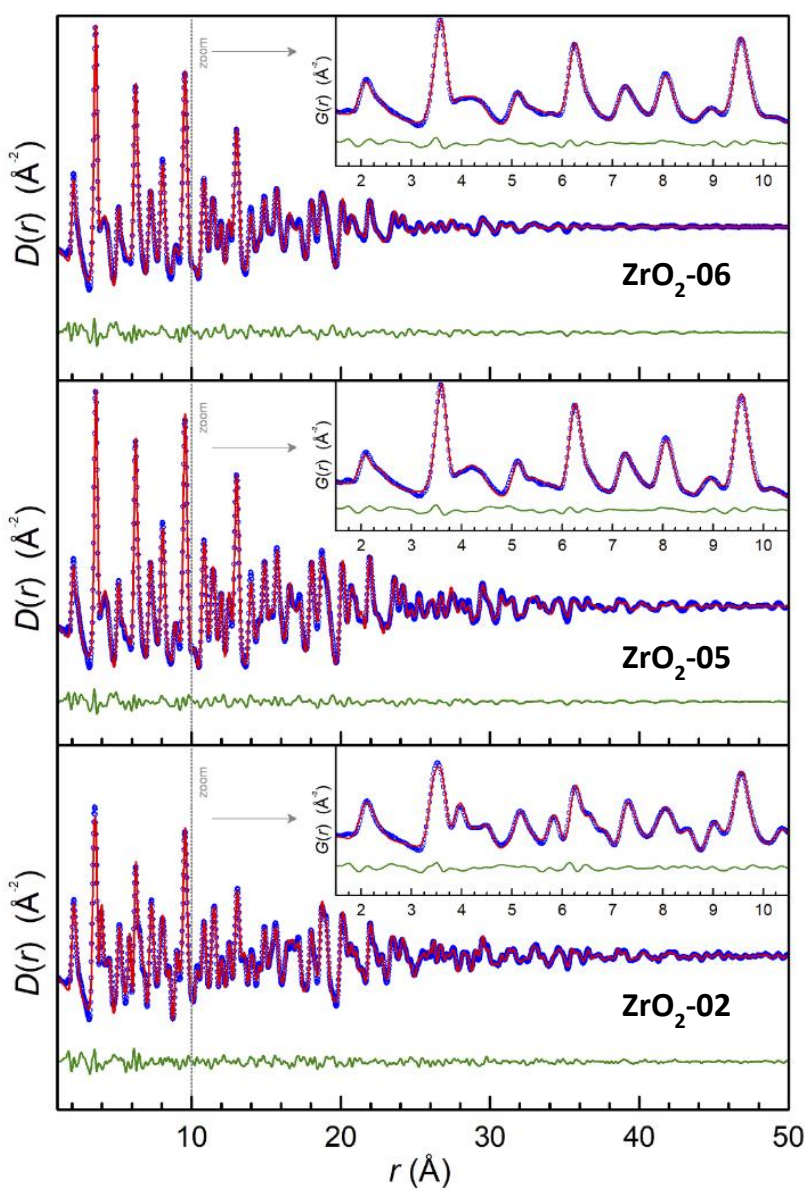

Figure VII: Differential correlation functions $D(r)$ obtained for powders $\mathrm{ZrO}_{2}-02,05$ and 06 in the 1.7-50 A range. Blue dotted lines, red and green curves symbolize the experimental data sets ( $\mathrm{D}(\mathrm{r})$ functions), the best fit and difference, respectively. The insets are the PDFs for each of the 3 measured samples in the 1.5-10.5 A range.

The Fourier transform clearly shows well resolved peaks at $\approx 2$ and $3.7 \AA$ attributable to $\mathrm{Zr}-\mathrm{O}$ and $\mathrm{Zr}$ - $\mathrm{Zr}$ nearest neighbor bond distances, respectively. The refined number of $\mathrm{O}$ atoms in the first and second coordination shells $\left(\mathrm{N}_{\mathrm{O} \text { (I) }}+\mathrm{N}_{\mathrm{O} \text { (II) }}\right)$ is $\approx 8.6$. Taking into account an uncertainty larger than 1 , this result is consistent with the expected value of 8 for a tetragonal structure, and can be considered as reasonable. Moreover, the decrease in surface metal-metal coordination number comparatively to core metal-metal coordination number can be explained by the confinement of the crystallite surface creating different local environments between surface and core metal atoms ${ }^{69}$ a)

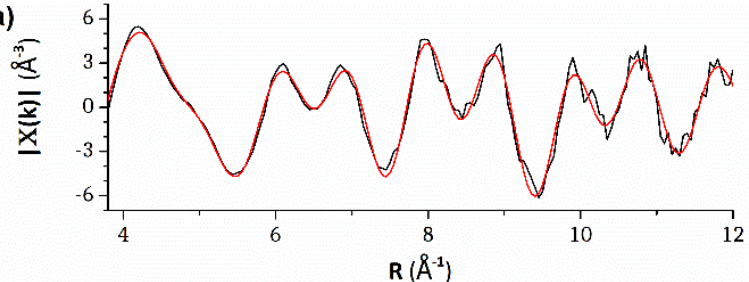

b)

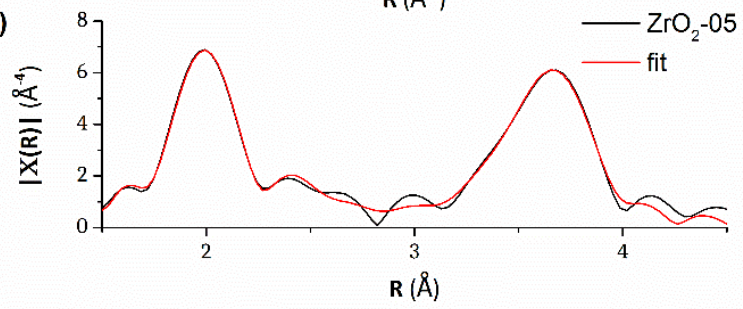

Figure VIII. a) $\mathrm{Zr}$ K-edge normalized EXAFS spectra of $\mathrm{ZrO}_{2}$ 05 powder, and b) the corresponding Fourier transform (black lines) corrected with the phase shift of the first coordination shell; its associated best fit (red line).

This phenomenon leads therefore to an overestimation of the $\mathrm{N}_{\mathrm{O}}$ coordination number. Thus, the number of $\mathrm{O}$ nearest neighbors and their associated uncertainties do not allow us to distinguish between the monoclinic and tetragonal structures, displaying 7 and $8 \mathrm{O}$ atoms per unit cell, respectively. Also, the refined $\mathrm{Zr}-\mathrm{O}$ distances $\mathrm{R}_{\mathrm{Zr}-\mathrm{O} \text { (I) }}$ and $\mathrm{R}_{\mathrm{Zr}-\mathrm{O} \text { (II) }}$ were $2.11 \pm 0.07 \AA$ and $2.30 \pm 0.07 \AA$, respectively. This is in quite good agreement with the distances estimated from the PDF data where the $\mathrm{d}_{\mathrm{Zr}-}$ O(I) was estimated at $2.07 \pm 0.01 \AA$ and the $\mathrm{d}_{\mathrm{Zr} \text {-O(II) }} 2.38 \pm 0.01$ $\AA$, keeping in mind that the PDF data includes overlapping atom pair information making it less reliable than X-ray absorption spectroscopy. These values, though close to that of the model, are hardly distinguishable from those of the monoclinic structure, displaying $5 \mathrm{Zr}$-O distances ranging from $2.03 \AA$ up to 2.26 $\AA$. When looking at the $\mathrm{Zr}-\mathrm{Zr}$ shell, a refined number of $\mathrm{Zr}$ atoms $\mathrm{N}_{\mathrm{Zr}}$ of $9.6 \pm 1.4$ is obtained, which is slightly lower than 12 expected for a pure tetragonal structure but too high for a monoclinic structure where a value of $\mathrm{N}_{\mathrm{Zr}}=6$ is expected. However, the refined $\mathrm{Zr}-\mathrm{Zr}$ distance $\mathrm{R}_{\mathrm{Zr}-\mathrm{Zr}}=3.64 \pm 0.09 \AA$ is very close to the single $\mathrm{Zr}-\mathrm{Zr}$ bond distance of the tetragonal model (3.56 $\AA$ ) that was used to perform FEFF calculation and fit the experimental data, while for a monoclinic structure two shorter $\mathrm{Zr}-\mathrm{Zr}$ bond distances are generally observed at $3.34 \AA$ and $3.46 \AA$. For information, the distances estimated from the PDF data were divided into two contributions the $\mathrm{d}_{\mathrm{Zr}-\mathrm{Zr}(\mathrm{I})}$ and $\mathrm{d}_{\mathrm{Zr}-\mathrm{Zr}(\mathrm{II})}$ with values of $3.60 \pm 0.01 \AA$ and $3.63 \pm 0.01 \AA$, which is in good agreement with EXAFS. Therefore, the obtained fitting results tend to indicate the existence of an intermediate structure which is not clearly tetragonal, neither monoclinic ${ }^{25,70,71}$. In addition, for very small nanoparticles, the proportion of surface atoms over core ones increases dramatically, in our case, for a $2 \mathrm{~nm}$ spherical particle, since the $\mathrm{Zr}-\mathrm{Zr}$ distance is $3.64 \AA$, there are approximately only five $\mathrm{Zr}$ atoms across the particle diameter, meaning two at the surface and three in the core. Knowing that surface $\mathrm{Zr}$ atoms are generally not fully coordinated, this also supports our observation of an intermediate structure, especially regarding the local environment of $\mathrm{Zr}$ atoms and its coordination to $\mathrm{O}$ atoms.

\section{Conclusion:}


The present work has demonstrated the phase fraction of $\mathrm{m}$ - and $\mathrm{t}-\mathrm{ZrO}_{2}$ structural polymorphs can be tuned by varying the amounts of water present during syntheses under supercritical conditions. When $\mathrm{ZrO}_{2}$ was synthesized in pure supercritical water, the final nanoparticles exhibited purely the monoclinic structure. However, when the absolute amounts of water were decreased, the percentage of $\mathrm{m}-\mathrm{ZrO}_{2}$ decreased relatively to $\mathrm{t}$ $\mathrm{ZrO}_{2}$ in the final powders. The sudden change in structure proportions and stagnation to the minimum observed between $\mathrm{ZrO}_{2}-04$ and 05 was attributed first of all to the pre-polymerization of nuclei with local structures close to $\mathrm{m}-\mathrm{ZrO}_{2}$ at the mixing point $\left(150^{\circ} \mathrm{C}\right)$, thus facilitating $\mathrm{ZrO}_{7}$ polyhedra packing for powders 01 to 03 , and secondly to the surface strain with the particle due to the size effect inducing distortion in the structure.

The lowest amounts of water achieved in our synthesis conditions were generated in situ from supercritical ethanol dehydration and led to $\mathrm{m}$ - and $\mathrm{t}-\mathrm{ZrO}_{2}$ nanoparticles with similar A.C.S. of 3.5 and $2.8 \mathrm{~nm}$, respectively and to $\approx 13 \mathrm{wt}$. $\% \mathrm{~m}-\mathrm{ZrO}_{2}$ in the final powders for a precursor concentration of $6.610^{-2} \mathrm{~mol} / \mathrm{L}$. Also, the use of hexanoic acid as surface modifiers helped to reduce both $\mathrm{t}-\mathrm{ZrO}_{2}$ A.C.S. down to $2.4 \mathrm{~nm}$ and size distribution, while maintaining a high degree of crystallinity as revealed by HRTEM diffraction images. However, hexanoic acid did not seem to favor $\mathrm{t}-\mathrm{ZrO}_{2}$ formation in terms of molar fractions, but did however in terms of number of $\mathrm{t}-\mathrm{ZrO}_{2}$ nanoparticles formed which was evidenced in this work and truly interesting in the comprehension of $\mathrm{ZrO}_{2}$ nanoparticle formation, thus clearly emphasizing the simultaneous nucleation of both structures rather than selection of a reactional pathway by decreasing the nanoparticle size. Also, Fourier transform of Zr K edge EXAFS for the sample containing one of the highest percentage of $t$ $\mathrm{ZrO}_{2}$ based on Raman $\left(\mathrm{ZrO}_{2}-05\right)$ revealed a tetragonal structure with slightly reduced metal-metal correlations relatively to metal-oxygen correlations, which is representative of nanomaterials containing significant levels of lattice disorder.

While it is possible that some critical size for the stabilization of tetragonal zirconia exists below $2 \mathrm{~nm}$, sensitive high energy $\mathrm{X}$-ray instruments and careful analysis would like be required to confirm. However, our results presented here suggest instead that reaction pathways and the resulting $\mathrm{ZrO}_{2}$ polymorph stabilization depends strongly on structural nucleation, L.O.I.V. concentrations, reaction kinetics and critically, in supercritical conditions, on water releasing rates. Therefore, though the particle size remains an important factor in achieving metastable $\mathrm{t}-\mathrm{ZrO}_{2}$ nanoparticles, its stabilization may not result solely from geometric size factor.

Overall, the combination of these analyses confirmed that the control of reaction kinetics through in situ water generation greatly helped to favor $\mathrm{t}-\mathrm{ZrO}_{2}$ formation, even if traces of $\mathrm{m}$ $\mathrm{ZrO}_{2}$ were still observed in the final powders.

\section{AUTHOR INFORMATION}

\section{Corresponding Author}

* cyril.aymonier@icmcb.cnrs.fr

\section{Author Contributions}

The manuscript was written through contributions of all authors. All authors have given approval to the final version of the manuscript.

\section{Funding Sources}

The work presented is carried out with funding from the Innovation Fund Denmark (GCAM) for A. Auxéméry.

\section{Notes}

The authors declare no competing financial interest.

\section{ACKNOWLEDGMENT}

The authors acknowledge the support of the Innovation Fund Denmark (GCAM), the Centre National de la Recherche Scientifique (CNRS) and the Région Nouvelle Aquitaine. The authors also acknowledge the European Synchrotron Radiation Facility for provision of synchrotron radiation beamtime and facilities, the FAME team for assistance in using their beamline and the Diamond Light Source for mail-in PDF measurement access at Beamline I15-1 under Proposal CY22774.

\section{REFERENCES}

(1) Auxéméry, A.; Frias, B. B.; Smal, E.; Dziadek, K.; Philippot, G.; Legutko, P.; Simonov, M.; Thomas, S.; Adamski, A.; Sadykov, V.; Parkhomenko, K.; Roger, A. C.; Aymonier, C. J. Supercrit. Fluids 2020, 162.

(2) Geethalakshmi, K.; Prabhakaran, T.; Hemalatha, J. World Academy of Science, Engineering \& Technology 2012, 64, 179.

(3) Kukli, K.; Ritala, M.; Aarik, J.; Uustare, T.; Leskelä, M. J. Appl. Phys. 2002, 92 (4), 1833-1840.

(4) Zakeri, M.; Rahimipour, M. R.; Jamal Abbasi, B. Mater. Technol. 2013, 28 (4), 181-186.

(5) Cameron, M. A.; George, S. M. Thin Solid Films 1999, 348 (1), 90-98.

(6) Gao, P.; Meng, L. J.; dos Santos, M. P.; Teixeira, V.; Andritschky, M. Vacuum 2000, 56 (2), 143-148.

(7) Yashima, M.; Morimoto, K.; Ishizawa, N.; Yoshimura, M. J. Am. Ceram. Soc. 1993, 76 (7), 1745-1750.

(8) Yashima, M.; Ohtake, K.; Kakihana, M.; Yoshimura, M. J. Am. Ceram. Soc. 1994, 77 (10), 2773-2776.

(9) Catlow, C. R. A.; Chadwick, A. V.; Greaves, G. N.; Moroney, L. M. J. Am. Ceram. Soc. 1986, 69 (3), 272-277.

(10) Li, P.; Chen, I.-W.; Penner-Hahn, J. E. Phys. Rev. B 1993, 48 (14), 10074-10081.

(11) Li, P.; Chen, I.-W.; Penner-Hahn, J. E. J. Am. Ceram. Soc. 1994, 77 (1), 118-128.

(12) Kim, D.-J. J. Am. Ceram. Soc. 1990, 73 (1), 115- 
120.

(13) Srinivasan, R.; Harris, M. B.; Simpson, S. F.; Angelis, R. J. De; Davis, B. H. J. Mater. Res. 1988, 3 (4), 787-797.

(14) Ouyang, H.; Li, C.; Li, K.; Li, H.; Zhang, Y. J. Wuhan Univ. Technol. Sci. Ed. 2016, 31 (1), 68-73.

(15) Tyrsted, C.; Becker, J.; Hald, P.; Bremholm, M.; Pedersen, J. S.; Chevallier, J.; Cerenius, Y.; Iversen, S. B.; Iversen, B. B. Chem. Mater. 2010, 22 (5), 1814-1820.

(16) Bokhimi, X.; Morales, A.; Novaro, O.; Portilla, M.; López, T.; Tzompantzi, F.; Gómez, R. J. Solid State Chem. 1998, 135 (1), 28-35.

(17) Zhan, Z.; Zeng, H. C. J. Mater. Res. 1998, 13 (8), 2174-2183.

(18) Malakooti, R.; Mahmoudi, H.; Hosseinabadi, R.; Petrov, S.; Migliori, A. $R S C A d v$. 2013, 3 (44), 22353-22359.

(19) Santos, V.; Zeni, M.; Bergmann, C. P.; Hohemberger, J. M. Rev. Adv. Mater. Sci. 2008, 17, $62-70$.

(20) Garvie, R. C. J. Phys. Chem. 1965, 69 (4), 1238 1243.

(21) Garvie, R. C. J. Phys. Chem. 1978, 82 (2), 218-224.

(22) Chraska, T.; King, A. H.; Berndt, C. C. Mater. Sci. Eng. A 2000, 286 (1), 169-178.

(23) Djurado, E.; Bouvier, P.; Lucazeau, G. J. Solid State Chem. 2000, 149 (2), 399-407.

(24) Joo, J.; Yu, T.; Kim, Y. W.; Park, H. M.; Wu, F.; Zhang, J. Z.; Hyeon, T. J. Am. Chem. Soc. 2003, 125 (21), 6553-6557.

(25) Igawa, N.; Ishii, Y.; Nagasaki, T.; Morii, Y.; Funahashi, S.; Ohno, H. J. Am. Ceram. Soc. 1993, 76 (10), 2673-2676.

(26) Shukla, S.; Seal, S. Int. Mater. Rev. 2005, 50 (1), 4564.

(27) Tsunekawa, S.; Ito, S.; Kawazoe, Y.; Wang, J.-T. Nano Lett. 2003, 3 (7), 871-875.

(28) Adamski, A.; JAKUBUS, P.; Sojka, Z. Mater. Sci. 2008, 26 (2), 373-380.

(29) Nawale, A. B.; Kanhe, N. S.; Bhoraskar, S. V.; Mathe, V. L.; Das, A. K. Mater. Res. Bull. 2012, 47 (11), 3432-3439.

(30) Valmalette, J. C.; Isa, M. Chem. Mater. 2002, 14 (12), 5098-5102.

(31) Tani, E.; Yoshimura, M.; Sōmiya, S. J. Am. Ceram. Soc. 1983, 66 (1), 11-14.

(32) Srinivasan, R.; Angelis, R. De; Davis, B. H. J. Mater. Res. 1986, 1 (4), 583-588.

(33) Adamski, A.; Jakubus, P.; Sojka, Z. Nukleonika 2006, Vol. 51,su, 27-33.

(34) Shukla, S.; Seal, S. J. Phys. Chem. B 2004, 108 (11),
3395-3399.

(35) De Keukeleere, K.; De Roo, J.; Lommens, P.; Martins, J. C.; Van Der Voort, P.; Van Driessche, I. Inorg. Chem. 2015, 54 (7), 3469-3476.

(36) Tana, F.; Messori, M.; Contini, D.; Cigada, A.; Valente, T.; Variola, F.; De Nardo, L.; Bondioli, F. Prog. Org. Coatings 2017, 103, 60-68.

(37) Omata, T.; Goto, Y.; Otsuka-Yao-Matsuo, S. Sci. Technol. Adv. Mater. 2007, 8 (6), 524-530.

(38) Becker, J.; Hald, P.; Bremholm, M.; Pedersen, J. S.; Chevallier, J.; Iversen, S. B.; Iversen, B. B. ACS Nano 2008, 2 (5), 1058-1068.

(39) Adschiri, T.; Hakuta, Y.; Arai, K. Ind. Eng. Chem. Res. 2000, 39 (12), 4901-4907.

(40) Wang, Q.; Li, C.; Guo, M.; Hu, C.; Xie, Y. J. Mater. Chem. A 2014, 2 (5), 1346-1352.

(41) Adschiri, T.; Yoko, A. J. Supercrit. Fluids 2018, 134, 167-175.

(42) Aymonier, C.; Philippot, G.; Erriguible, A.; Marre, S. J. Supercrit. Fluids 2018, 134 (October 2017), 184-196.

(43) Darr, J. A.; Zhang, J.; Makwana, N. M.; Weng, X. Chem. Rev. 2017, 117, 11125-11238.

(44) Philippot, G.; Elissalde, C.; Maglione, M.; Aymonier, C. Adv. Powder Technol. 2014, 25 (5), 1415-1429.

(45) Slostowski, C.; Marre, S.; Babot, O.; Toupance, T.; Aymonier, C. Langmuir 2012, 28 (48), 1665616663.

(46) Dippel, A.-C.; Jensen, K. M. Ø.; Tyrsted, C.; Bremholm, M.; Bøjesen, E. D.; Saha, D.; Birgisson, S.; Christensen, M.; Billinge, S. J. L.; Iversen, B. B. Acta Crystallogr. Sect. A Found. Adv. 2016, 72 (6), 645-650.

(47) Eom, H.-J.; Kim, M.-S.; Lee, D.-W.; Hong, Y.-K.; Jeong, G.; Lee, K.-Y. Appl. Catal. A Gen. 2015, 493, 149-157.

(48) Masoodiyeh, F.; Karimi-Sabet, J.; Khanchi, A. R.; Mozdianfard, M. R. Powder Technol. 2015, 269, 461-469.

(49) Demoisson, F.; Ariane, M.; Piolet, R.; Bernard, F. Adv. Eng. Mater. 2011, 13 (6), 487-493.

(50) Tyrsted, C.; Pauw, B. R.; Jensen, K. M. Ø.; Becker, J.; Christensen, M.; Iversen, B. B. Chem. - A Eur. J. 2012, 18 (18), 5759-5766.

(51) Py, W.; K, U.; H, T.; K, K. J. Supercrit. Fluids 2013, 78, 124-131.

(52) Debecker, D. P.; Mutin, P. H. Chem. Soc. Rev. 2012, 41 (9), 3624-3650.

(53) Styskalik, A.; Skoda, D.; Barnes, C. E.; Pinkas, J. Catalysts 2017, 7 (6), 168.

(54) Bondesgaard, M.; Becker, J.; Xavier, J.; Hellstern, H.; Mamakhel, A.; Iversen, B. B. J. Supercrit. Fluids 
2016, 113, 166-197.

(55) Philippot, G.; Albino, M.; Chung, U.-C. U.-C.; Josse, M.; Elissalde, C.; Maglione, M.; Aymonier, C. Mater. Des. 2015, 86 (March 2016), 354-360.

(56) Philippot, G.; Boejesen, E.; Elissalde, C.; Maglione, M.; Aymonier, C.; Iversen, B. Chem. Mater. 2016, 28 (10), 3391-3400.

(57) Lemmon, E. W.; Bell, I. H.; Huber, M. L.; McLinden, M. O. 2018.

(58) Rodríguez-Carvajal, J. Phys. B Condens. Matter 1993, $192(1-2), 55-69$.

(59) Proux, O.; Biquard, X.; Lahera, E.; Menthonnex, J. J.; Prat, A.; Ulrich, O.; Soldo, Y.; Trvisson, P.; Kapoujyan, G.; Perroux, G.; Taunier, P.; Grand, D.; Jeantet, P.; Deleglise, M.; Roux, J.; Hazemann, J. Phys. Scr. 2005, 970.

(60) Ravel, B.; Newville, M. J. Synchrotron Radiat. 2005, 12 (4), 537-541.

(61) Coelho, A. A.; Chater, P. A.; Kern, A. J. Appl. Crystallogr. 2015, 48 (3), 869-875.

(62) McAfee, L. J. Chem. Educ. 2000, 77 (9), 1122.

(63) Giroire, B.; Slostowski, C.; Marre, S.; Aymonier, C.; Aida, T.; Hojo, D.; Aoki, N.; Takami, S.; Adschiri, T. Phys. Chem. Chem. Phys. PCCP 2016, 18 (3), 1727-1734.

(64) Bouvier, P.; Djurado, E.; Ritter, C.; Dianoux, A. J.; Lucazeau, G. Int. J. Inorg. Mater. 2001, 3 (7), 647654.

(65) Keramidas, V. G.; White, W. B. J. Am. Ceram. Soc. 1974, 57 (1), 22-24.

(66) Alzyab, B.; Perry, C. H.; Ingel, R. P. J. Am. Ceram. Soc. 1987, 70 (10), 760-765.

(67) Chadwick, A. V.; Mountjoy, G.; Nield, V. M.; Poplett, I. J. F.; Smith, M. E.; Strange, J. H.; Tucker, M. G. Chem. Mater. 2001, 13 (4), 1219-1229.

(68) Sadykov, V. A.; Zaikovskii, V. I.; Zyuzin, D. A.; Moroz, E. M.; Burgina, E. B.; Ishchenko, A. V.; Kostrovskii, V. G.; Matyshak, V. A. MRS Online Proc. Libr. Arch. 2005, 878.

(69) Yuren, W.; Kunquan, L.; Dazhi, W.; Zhonghua, W.; Zhengzhi, F. J. Phys. Condens. Matter 1994, 6 (3), 633-640.

(70) Osendi, M. I.; Moya, J. S.; Serna, C. J.; Soria, J. J. Am. Ceram. Soc. 1985, 68 (3), 135-139.

(71) Gómez, R.; López, T.; Bokhimi, X.; muñoz, E.; boldú, J. L.; Novaro, O. J. Sol-Gel Sci. Technol. 1998, 11 (3), 309-319. 


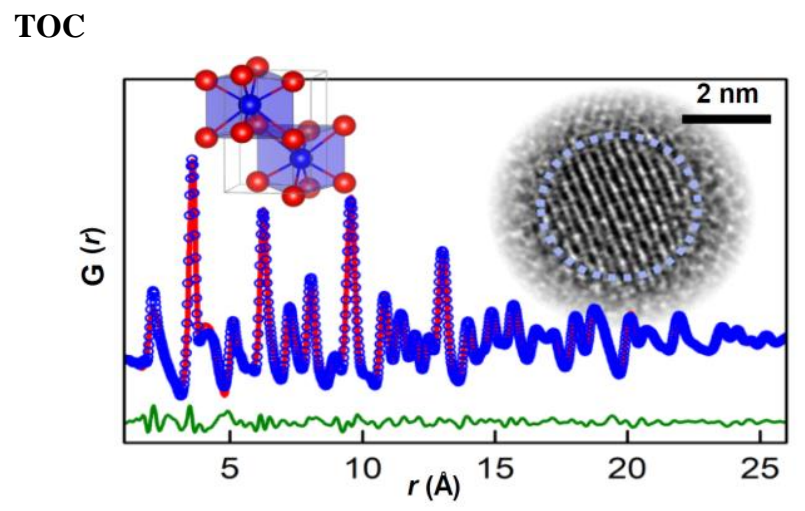

14 